\title{
Cross-pollinating in the beehive: embracing hybridity at a social entrepreneurship coworking space
}

\author{
Julie Fabbri and Benjamin Huybrechts \\ emlyon business school \\ Draft version - please do not cite or quote
}

\begin{abstract}
How does participating in a coworking space enable entrepreneurs to embrace plural institutional logics and engage in "hybrid venturing"? To explore this question, our research draws on a longitudinal study of a French coworking space gathering entrepreneurs who seek to reconcile social and commercial logics in the context of a socially entrepreneurial project. As social entrepreneurs generally lack pre-established patterns specific to this "hybrid" venturing mode, we show that the interactions at the coworking space help them embrace hybridity through (1) identifying with a community of peer, like-minded entrepreneurs; (2) collectively learning about and experimenting with this venturing mode, through their own projects but also through the coworking space as a hybrid venture in itself; and (3) connecting with and contributing to building the emerging ecosystem around hybrid venturing. The perception of the coworking experience, however, varies depending on the previous background of the entrepreneurs and in particular their familiarity with each of the logics at play. We thus document how, building upon their given ex-ante familiarity with the logics in presence, entrepreneurs with different backgrounds take the opportunity of interacting in the coworking space to "hybridize" their profile and, as a consequence, their venture. These findings contribute to the literatures on hybrid venturing and organizing, coworking spaces, and social entrepreneurship.
\end{abstract}

\section{Keywords}

Hybrid venture, hybrid organizing, institutional logics, entrepreneurial interactions, social entrepreneurship, coworking space 
I was a proud member of the team that pulled this coworking space off in 2008 with the dream to create an empowering environment for entrepreneurs with a purpose. There were hardly no coworking spaces in Paris and social entrepreneurship was only emerging. It feels really great to benefit from the desired future we imagined 10 years back. (Amaury, staff member, 2019)

\section{Introduction}

Over the last decade, there has been growing attention to new "hybrid" forms of venturing that bridge distinct organizational forms and their attendant institutional logics - for example, scientific and commercial logics for academic spin-offs and industry research centres (Murray, 2010; Perkmann, McKelvey, \& Phillips, forthcoming), or social and commercial logics in the case of social entrepreneurship (Battilana \& Lee, 2014; McMullen, 2018). Extant research has documented the opportunities, but also the challenges, of building and sustaining hybrid ventures due to the tensions and paradoxes involved in combining distinct and potentially contradictory logics (Grimes, Williams, \& Zhao, forthcoming; Ramus \& Vaccaro, 2017). Much of this research, however, focuses on already established hybrid ventures, and, moreover, examines each venture in isolation (McMullen, 2018). By doing so, extant research first of all tends to overshadow the early phases of organizational creation. While there has been some work on the profiles of entrepreneurs engaging in hybrid venturing, alone or in teams (Dufays \& Huybrechts, 2016; Lee \& Battilana, 2013), we know little about the ways through which hybrid ventures take shape and, in particular, how entrepreneurs come to integrate plural logics within the creation of their venture (Battilana \& Lee, 2014).

This question is even more important when taking into account the fact that entrepreneurs do not operate in isolation but rather interact and influence each other when creating their venture (Ebbers, 2014; Mitev, de Vaujany, Laniray, Bohas, \& Fabbri, 2018). Therefore, hybridity should also be examined in relation to collective dynamics, not only within teams managing a common venture, but also across different ventures. While some research has examined how established hybrid ventures join together through partnerships and networks (Bergman, 2017; Huybrechts \& Haugh, 2018; York, Hargrave, \& Pacheco, 2016), the interactions among entrepreneurs when developing hybrid ventures have received scant attention so far. Understanding these interactions is important in the context of the growing importance of 
collaborative settings in the entrepreneurial process, including collaborative spaces such as incubators, accelerators and, as is the focus of this paper, coworking spaces (Blagoev, Costas, \& Kärreman, 2019; Garrett, Spreitzer, \& Bacevice, 2017).

Coworking spaces offer an interesting setting in which peer-to-peer interactions take place (Autio, Nambisan, Thomas, \& Wright, 2018) because, due to the large autonomy left to participants and the lack of pre-established collaboration program (Garrett et al., 2017), these interactions tend to be more informal and less structured than, for example, in business incubators and accelerators (Giudici, Combs, Cannatelli, \& Smith, forthcoming; Ometto, Gegenhuber, Winter, \& Greenwood, forthcoming). As "interstitial spaces" (Furnari, 2014) connecting different spheres, coworking spaces have been shown to provide opportunities for interaction and exchange among diverse entrepreneurs (Vidaillet \& Bousalham, forthcoming) and to build their sense of community (Gandini, 2015; Garrett et al., 2017). However, while the characteristics and potential of coworking spaces have started to be investigated (Garrett et al., 2017), the perception of this experience by entrepreneurs with different backgrounds have been poorly documented so far (Butcher, 2018). Bearing different levels of familiarity with the logics at play (Lee \& Battilana, 2013; Pache \& Santos, 2013a), entrepreneurs engaged in developing hybrid ventures face the collective challenge of developing venture forms that are not yet fully recognized within the entrepreneurial ecosystem (Aldrich \& Fiol, 1994; Battilana \& Lee, 2014; McMullen, 2018). In this paper, we document whether and how participating in a coworking space may help entrepreneurs embrace hybridity while developing their entrepreneurial project, taking into account their ex-ante familiarity of entrepreneurs with regard to the logics in presence (Pache \& Santos, 2013a). Capturing how entrepreneurs with different logic backgrounds interact in a coworking space while creating their ventures is important to better understand the formation of hybrid ventures, in between purely individual-level and organization-level analyses (Grimes et al., forthcoming). Our research is thus guided by the following question: "How may participating in a coworking space help entrepreneurs embrace hybrid venturing?".

To respond to this question, our research draws on a longitudinal study of a French coworking space gathering would-be social entrepreneurs. After extensive research on the space and its use by the coworker entrepreneurs from 2010 to 2013, we returned to interview the same entrepreneurs several years later to understand their evolution in relation to hybrid venturing. While all the interviewed entrepreneurs valued the role of the coworking space in building a 
sense of community and identification, and in participating in constructing the emerging "hybrid" ecosystem (in this case social entrepreneurship), entrepreneurs had more contrasted views regarding how the experience helped them to experiment with and translate hybrid venturing into practice. These contrasted views could be partly related to the different types of backgrounds in terms of ex-ante familiarity with social and commercial logics. Entrepreneurs with either a social or a commercial background were most in demand to use the coworking space experience to learn to acquire their missing logic and integrate it into their venture. Compared with the other profiles, these entrepreneurs expressed more disappointment about some aspects of the coworking space, although they tended to be more involved in its development and were globally satisfied about their experience. Entrepreneurs with equal (either high or low) familiarity with social and commercial logics, on the other hand, had less specific expectations about the coworking space and were more satisfied about the way in which their experience helped them to forge, or consolidate, an orientation towards hybrid venturing.

These findings contribute to the literature in at least three ways. To the literature on hybridity, we show how the coworking space experience generally reinforces the commitment to hybrid venturing, complementing extant work either on hybrid entrepreneurs taken individually (Dufays \& Huybrechts, 2016; Lee \& Battilana, 2013), or on collaboration among already established hybrid ventures (Bergman, 2017; York et al., 2016). Second, our work adds to the emerging literature on collaborative spaces and coworking spaces in particular (Blagoev et al., 2019; Mitev et al., 2018) by enriching our understanding of how entrepreneurs perceive their experience not only in real time but also with a reflexive distance. Moreover, their experience perception is connected with their ex-ante background, which has not been considered so far in the literature on coworking and collaborative spaces. This is particularly useful to capture how entrepreneurs complement their initial background thanks to the coworking space experience, and how this enables them to embrace hybridity and integrate it into their ventures. Finally, the research also contributes to the literature and practice of social entrepreneurship by highlighting the conditions through which coworking spaces contribute to the emergence and development of social entrepreneurs, besides extant work on social entrepreneurship networks, incubators and competitions (Meyskens, Robb-Post, Stamp, Carsrud, \& Reynolds, 2010; Nicholls, 2010). 


\section{Theory}

\section{Hybrid venturing}

Building new ventures is challenging, even more so when the organizational form of the ventures is not yet taken for granted (Aldrich \& Fiol, 1994). This is the case of hybrid ventures that assemble structural characteristics, and their associated institutional logics, from distinct established organizational forms (Battilana \& Lee, 2014). For example, social enterprises combine the social logic of the non-profit form with the commercial logic underlying the forprofit business form (Besharov \& Smith, 2014). Institutional logics are a set of 'material practices and symbolic constructions' that represent the organizing principles of society and that are 'available to organizations and individuals to elaborate' (Friedland and Alford, 1991: 248). Drawing upon extant cultural material (Thornton, 2004), such logics inform the behaviour of individual actors within a field, and make action 'comprehensible and predictable' to others (Lounsbury, 2002: 255). Although hybridity of logics, as a continuous variable, is observable across virtually all organizations (Shepherd, Williams, \& Zhao, forthcoming), hybrid ventures, or organizations, are those whose core identity is defined by the structural combination of two or more logics (Besharov \& Smith, 2014).

Much research has examined how to manage hybridity at the organizational level (Battilana, Sengul, Pache, \& Model, 2015; Ebrahim, Battilana, \& Mair, 2014) to avoid the dominance of one logic over the other, an evolution coined as "mission drift" (Battilana \& Lee, 2014; Grimes et al., forthcoming). By contrast, while scholars have paid some attention to the characteristics of those founding hybrid ventures (Dufays \& Huybrechts, 2016; Lee \& Battilana, 2013), the process through which entrepreneurs come to embrace hybridity while creating their venture has remained largely unexplored. Examining this process requires understanding how hybridity unfolds at the individual level. Previous research has documented how individuals facing plural logics position themselves in function of their degree of familiarity with each of these logics (Bertels \& Lawrence, 2016; Pache \& Santos, 2013a). Such familiarity is encapsulated into the individuals" "institutional biography” (Bertels \& Lawrence, 2016; Lawrence, Suddaby, \& Leca, 2011) that shapes their engagement with, and possible combination of, plural logics. Hybridity emerges most naturally from equal engagement with both logics: either because of engagement with none of the logics, which Battilana and Dorado (2010) describe as a "tabula rasa" situation from which individuals may be socialized into both logics; or because of individuals' high 
engagement with both logics in presence, enabling them to become "hybridizers" in their organization (Pache \& Santos, 2013a).

Translating the configuration of logics to the specific case of entrepreneurs (Spedale $\&$ Watson, 2014), hybridity may be "imprinted" into nascent ventures when individuals have developed familiarity with plural logics thanks to their previous experience and/or educational background (Lee \& Battilana, 2013). Yet, other authors have shown that hybrid ventures do not necessarily require entrepreneurs familiar with plural logics from the outset but may emerge from the team work of founders who each carry different logics (Almandoz, 2012; Dufays \& Huybrechts, 2016). In any case, whether focusing on individual entrepreneurs or on teams, extant research has examined how hybridity unfolds in the context of individual ventures taken in isolation. In other words, whether a venture may become a hybrid or not depends on the a priori characteristics of that venture. It therefore ignores the possibility of cross-pollination across different ventures developed by entrepreneurs with different levels of familiarity with the logics at play. Examining how would-be hybrid entrepreneurs interact and influence each other when their ventures are under construction is important to extend our understanding of the emergence of hybrids beyond given ventures taken in isolation. Indeed, in the same way as established hybrids join together in institutional work (Huybrechts \& Haugh, 2018; York et al., 2016), so can entrepreneurs facing the collective challenge of developing and legitimizing hybridity when their ventures are under construction. To examine how interactions unfold among would-be hybrid entrepreneurs, we suggest that collaborative spaces and more particularly coworking spaces, thanks to the features described next, are a particularly intriguing context likely to play an important role in enabling entrepreneurs to individually and collectively embrace hybridity.

\section{Coworking spaces and the development of hybrid ventures}

Coworking spaces are a relatively recent phenomenon and have only received limited scholarly attention so far (Blagoev et al., 2019; Garrett et al., 2017). Extant research focuses on coworking spaces as spatio-temporal settings (Fabbri, 2016) generating communities of practice (Bouncken \& Reuschl, 2018; Garrett et al., 2017); as (partial) organizations (Blagoev et al., 2019); or as laboratories of new working practices (Brown, 2017; Spinuzzi, 2012) and urban regeneration (Durante \& Turvani, 2018). Nevertheless, there has been less attention to how participating in a coworking space shapes the entrepreneurial behaviour of coworkers (Gerdenitsch, Scheel, Andorfer, \& Korunka, 2016), let alone the way in which they engage with plural institutional logics. 
From an entrepreneurial perspective, at first sight, coworking spaces can be assimilated with other business support spaces in which new ventures are nurtured, typically business incubators, accelerators, or science parks (Phan, Siegel, \& Wright, 2005). They similarly provide logistical and social support (Gerdenitsch et al., 2016), enabling entrepreneurs to start and grow their businesses (Fuzi, 2015). Nevertheless, we suggest that coworking spaces differ from incubators in at least two important ways. First, while incubators often have a specific vision regarding where to take the ventures and implement this vision through dedicated programs, staff and tools (Hackett \& Dilts, 2004; Phan et al., 2005), coworking spaces have no such predefined goal. While, in incubators, there is a vertical relationship between the incubator structure and the incubatees, with the former coaching the latter (Hackett \& Dilts, 2004), in coworking spaces, the relationships are mainly horizontal even when staff members animate the space (Garrett et al., 2017). Whereas in incubators, support programs are geared towards competence acquisition, successful funding and long-term performance (Allen \& McCluskey, 1990; Bruneel, Ratinho, Clarysse, \& Groen, 2012), at a coworking space such predefined goals are less precise if not absent (Brown, 2017), leading to more informal (Blagoev et al., 2019) and horizontal exchanges (Garrett et al., 2017).

Second, as a consequence of the relative lack of vertical business support program, the scope of ventures in coworking spaces tends to be broader, whether in terms of maturity stages and/or sectors in which the ventures operate. Indeed, because they need to offer certain level of tailored and consistent support (Hackett \& Dilts, 2004), incubators have tended to narrow down the scope of the participating ventures to specific sectors (Schwartz \& Hornych, 2008) and/or to specific stages of development (Allen \& McCluskey, 1990). By contrast, coworking spaces generally integrate a diversity of project holders that may either be nascent or confirmed entrepreneurs as well as, increasingly, employees of established companies who for various reasons have an interest in working there (Bouncken \& Reuschl, 2018). Such diversity is increasing as coworking spaces, together with other structures, enable more flexibility in moving between traditional and new forms of work (Mitev, de Vaujany, Laniray, Bohas, \& Fabbri, 2018). Coworkers typically join when space is available, and not following a specific call. Although there may be a broad orientation for the coworking space, for example urban development (Durante \& Turvani, 2018) or social entrepreneurship, as in the case examined in this paper, the diversity of statutes, projects and sectors of coworkers is likely to be higher than in incubators. 
Because of these two distinctive features - horizontal, peer-to-peer relationships and diversity of individuals and projects - coworking spaces enable mutual exchanges and experimentation in the context of learning communities (Bouncken \& Reuschl, 2018; Fabbri \& Charue-Duboc, 2013). They are part of what Furnari (2014) calls "interstitial spaces" in which people from different areas and driven by different logics come together to exchange, which may foster cross-pollination and experimentation. This, of course, resonates with the notion of hybrid venturing blending different logics and forms. The exposition to and experimentation with novel approaches at the intersection between diverse worlds, as enabled by coworking spaces (Vidaillet \& Bousalham, forthcoming), is likely to be even more important when entrepreneurs are creating their ventures. Indeed, unlike other participants in interstitial spaces, coworker entrepreneurs are in the process of making choices regarding whether and how they embrace different logics in presence and integrate them into their ventures (Dufays, 2019; Furnari, 2014).

The literature on coworking spaces has been very optimistic regarding their capacity to stimulate interactions and collaborative practices, building the coworkers' sense of community (Gandini, 2015; Garrett et al., 2017) and helping them enrich their projects (Brown, 2017). Yet, extant empirical research provides little examination of how coworker entrepreneurs perceive their experience of, and interactions in, this type of setting. Moreover, the diverse profiles of coworkers has not been examined so far, and little is known regarding the interaction between entrepreneurs with different logic backgrounds. Do these interactions enable entrepreneurs with diverse backgrounds to embrace plural logics and integrate hybridity into their ventures? If so, how? Our empirical setting precisely enables to capture such dynamics.

\section{Research design}

To capture the subjective dimension of individuals' experiences in their specific context, an interpretative qualitative research design was adopted and focused on an emblematic, exploratory case study (Yin, 2009). We chose to study the case of a French coworking space for social entrepreneurs, called "La Ruche" ("The Beehive"). Launched in May 2008, La Ruche was one of the major players in promoting social entrepreneurship at a time where this concept was only emerging in this country. It was also one of the two pioneer coworking spaces in France. These two characteristics justified the choice of this case in the light of our research 
question. First, as one of the pioneer spaces gathering social entrepreneurs (or in some cases "social intrapreneurs"), La Ruche enabled individuals to engage in social entrepreneurship as one emblematic type of hybrid venturing that combines two distinct logics, i.e. a commercial logic of using a business activity and a social logic of tackling a societal challenge (Battilana \& Lee, 2014). Indeed, all La Ruche coworkers, as other social entrepreneurs, work in relation to a cause concerning specific beneficiaries (e.g. work integration, fighting poverty, providing access to housing and affordable energy, etc.) and/or society as a whole (e.g. recycling, sustainable mobility, etc.). These entrepreneurs joined La Ruche at a time where the social entrepreneurship ecosystem was under construction and there was no established framework for engaging in this venturing mode, rendering peer-to-peer interactions and experimenting particularly instrumental. Second, as one of the first coworking spaces, La Ruche itself was under construction, with coworker entrepreneurs taking bottom-up decisions about how to best shape an interactive peer-to-peer setting. Observing and interviewing entrepreneurs during and after their experience thus enabled to yield reflexive insights regarding the purposive fit between the collaborative setting and the venturing mode adopted by the coworkers.

La Ruche is a not-for-profit social enterprise that covers its costs through the coworkers' rents. All surpluses are reinvested in the project. Its primary activity is to provide shared services and workspace $\left(600 \mathrm{~m}^{2}\right.$ open space containing eighty workstations) through a full-time ("resident") or a part-time membership. La Ruche also organizes workshops, conferences, and exhibitions for members but also for external attendants. During the observation period, members ranged from roughly 18 to 65 years of age and were balanced in terms of gender. Most coworkers were entrepreneurs -beginners or experienced-creating new businesses, but some coworkers were intrapreneurs and developed new products or services, or opened a new subsidiary for an existing social enterprise. Legal forms are also diverse: for-profit companies, non-profits, cooperatives, as well as sole entrepreneurs and freelancers may be hosted at La Ruche, as long as they can demonstrate that they develop a commercial activity to pursue a social goal. Such dual orientation is assessed by the recruitment committee -the managing team and a few voluntary full-time coworkers- when new coworkers apply. Coworkers have diverse backgrounds in terms of familiarity with social and commercial logics, as will be explained next.

\section{Data collection}


To capture both the real-time experience of the entrepreneurs during their stay at La Ruche and the ways in which this experience had fed their process of creating a hybrid venture, we organized two main data collection phases: the first between 2010 and 2013, and the second in 2018 and 2019. Between 2010 and 2013, the first author had a regular presence at the coworking space. She spent much time working on her research there, attended numerous informal events, 10 internal "buzz" meetings at lunchtime, and 12 other events organized by La Ruche (peer-topeer sessions, creativity workshops, open days...). Each time she was present at La Ruche, she discussed informally with various people in the coworking space (entrepreneurs, guests, coordinating team, etc.), she observed the interactions taking place, and she took daily notes to structure her observations. During this period, she also contacted all the coworkers who were (co)founders of the member ventures and present at La Ruche as of 2011 for an interview (63). She interviewed all those who responded positively (33), either formally with recording and transcription (24) or, when this was not possible, informally while taking extensive notes (9). Half of the coworkers were thus interviewed, making sure that the diversity of entrepreneurial profiles was represented in terms of prior experience and familiarity with social and/or commercial logics. Moreover, 6 entrepreneurs were interviewed twice during the 2010-2013 period. 28 of the interviewees were entrepreneurs and 5 were intrapreneurs. The sample includes 10 women. The focus was on on-going members, but the interviewees also included 3 former members of La Ruche and 4 entrepreneurs who were about to leave. The interview guide was made of various semi-open questions regarding their personal trajectories, the rationale for joining La Ruche, their involvement in the space, and the way in which they engaged with social and commercial logics. She also conducted 7 interviews with La Ruche staff members (president, coworking space managers, interns).

To better understand how the interviewed entrepreneurs viewed their coworking experience at a distance and related to hybrid venturing over time, a second data collection was led by all coauthors in 2018 and 2019. The second round brought a complementary perspective by enabling the entrepreneurs to step back regarding their experience as shared during the first phase. We started by collecting online data, screening LinkedIn profiles (64), company webpages (42) and organizational documents such as annual reports and press releases (11). We also consulted the official website providing legal and financial information on French companies to assess whether the ventures were still active. We were surprised to observe that $76 \%$ of the ventures met in the first phase still existed several years later, even if only $52 \%$ of our interviewees were still active in these ventures. We checked the consistency of these figures with regard to the 
whole population of the 63 entrepreneurs active in the coworking space during the first data collection, and observed similar rates (respectively $78 \%$ and $54 \%$ ).

Interestingly, all the ventures were still focused on the same social mission and pursued the same type of economic activity, showing no visible sign of "mission drift" (for example, change in legal form, statutes, or capital structure). Moreover, the large majority of those who were no longer active in their venture or whose venture had failed were still active in the domain of social entrepreneurship, either through creating a new social entrepreneurial project or by joining an existing one ( $79 \%$ for our sample and $73 \%$ out of the initial database). We contacted the 33 entrepreneurs initially interviewed between 2010 and 2013 and we were able to formally interview 26 of them. Such easiness to reconnect with the entrepreneurs came as a positive surprise. One of the reasons is that the entrepreneurs remained much attached to La Ruche even several years after they left, with numerous interactions among alumni, a shared La Ruche private Facebook group, and participation in La Ruche events. The interviews focused on their personal and venture evolutions before, during and after La Ruche, and on the retrospective perceptions of the coworking experience. Finally, we also formally re-interviewed the 3 main former staff members of La Ruche.

In summary, we conducted a total of 75 interviews with 33 social entrepreneurs and intrapreneurs, as well as 7 staff members. To ensure confidentiality, all the names were changed in the context of this study. The interviews lasted an average of 70 minutes. All the formal interviews (66) were recorded and transcribed. Table 1 summarizes the profiles of the interviewees.

\section{Insert Table 1 about here}

\section{Data analysis}

The data analysis followed an abductive reasoning, with regular interactions between theory and data (Eisenhardt, 1989). A thematic content analysis of the interviews and notes at the two periods of time was conducted using NVivo and following the coding structure proposed by Gioia et al. (2013). First, in 2013, the data was coded by the first author and a preliminary coding structure was proposed to map out the trajectories of the coworkers and how they considered that their coworking experience had helped (or restrained) them in embracing hybridity. It quickly appeared, however, that understanding the ways in which the coworking 
space experience had shaped their involvement in hybrid venturing required a longer timeframe, justifying the second data collection and more in-depth iterations with the literature on hybrid venturing. The extended dataset including the 2018-2019 interviews was the object of a second coding exercise, which each co-author did separately before agreeing on a common structure and enriching it with the help of more fine-grained theoretical insights at the intersection of hybrid venturing and coworking. All the information regarding the perceived role of the coworking space experience in terms of hybrid venturing was categorized into 16 specific firstorder codes. These codes were then grouped into 6 second-order codes reflecting the type of content to which the first-order codes could be connected, for example identifying with peers, learning to balance financial sustainability and social goals, or building credibility. Then, through further theoretical iterations, we grouped the second-order codes into 3 aggregate dimensions according to the main roles identified for the coworking space in reinforcing hybrid ventures: creating a community of hybrid entrepreneurs; collectively experimenting with the coworking space as a hybrid venture; and institutionalizing hybrid venturing.

In parallel, early in the coding process, we observed differences among the entrepreneurs in way in which they had experienced coworking at La Ruche. This led us to deepening the analysis to understand these differences. It quickly became apparent that the previous background of the coworkers played an important role in how they perceived their experience, and that entrepreneurs tended to engage even more intensely with colleagues with a similar background. Our observations and questions to staff members on this specific point enabled us to jointly identify four main profiles. Iterating with the literature on institutional logics at the individual level (Bertels \& Lawrence, 2016; Pache \& Santos, 2013a), we connected these profiles with the different possible combinations of familiarity with social and commercial logics. Table 2 maps out these four combinations and presents the bee-related names we gave to these four profiles, taking inspiration from the name of the coworking space ("The Beehive").

\section{Insert Table 2 about here}

(1) A first entrepreneurial profile consisted of individuals mainly familiar with the social logic because they had previously worked in charities, NGOs, or in the public sector in the context of addressing a societal challenge. We called these entrepreneurs "nurse bees" as these bees are in charge of caring for the brood and cleaning the hive. One example of this profile is Greta who launched a non-profit association to help parents with signing language after having worked 5 years as a childcare professional. 
(2) A second entrepreneurial profile - at the opposite of the first one- was made of individuals with a business background who were thus much more familiar with the commercial logic. In our sample as well as in the total population, this category was significantly larger than the three other categories. These entrepreneurs were named "drone bees", which unlike nurse bees do little around the hive and focus on their main task of mating. For example, Corentin used to work 11 years as regional sales director for a computer software company, after a master in international business, when he created the first consumer service for deaf people and joined La Ruche in 2009. At his arrival, he felt illegitimate in the coworking space due to his previous experience, despite the obvious social dimension of his entrepreneurial project.

(3) Third, "forager bees" fly from one flower to the other to collect nectar, pollen, and propolis. We thus chose this type of bee to designate entrepreneurs who had been socialized into both the social and the commercial logics, either because they had an experience in both the social and business sectors, or because they were already engaged in social entrepreneurship before joining the coworking space. One example of this profile is Philippe who, after diverse studies and experiences, became Delegate of Architecture, Urban Planning and Environment of the region Ile-de-France, where he worked on the topic of sustainable construction. He joined La Ruche in 2011 to develop a collaborative resource centre in this domain.

(4) Finally, certain coworkers had no or weak prior working experience and, although some of them came out of studies with a more social or business-oriented content, they were novices in terms of both business practice and social action. Lacking a specific name in the domain of bees, we chose "newbies" (renamed "newbees" for the sake of bee-relatedness) to reflect the novice character of these entrepreneurs. Flavien, for example, after a master thesis on "Web \& Solidarity" presented in 2009, joined La Ruche to develop social business solutions for Latin cultural events.

To connect this typology with the coding structure, we reexamined the first-order codes to examine similarities and differences between the 4 entrepreneurial profiles identified in terms of ex-ante familiarity with the social and commercial logics. Figure 1 depicts the coding structure and Table 3 proposes one emblematic quote among those identified at each intersection between the first-order codes and the four entrepreneurial profiles. The illustrative quotes for this table and for the text were professionally translated from French to English. 


\section{Findings}

Our findings are structured according to the 3 aggregate dimensions emerging from our data analysis.

\section{Building a local community of hybrid entrepreneurs}

\section{Adopting a hybrid entrepreneurial identity}

Before considering the added-value for their ventures, all entrepreneurs emphasized how interacting in the coworking space had enabled them to better define themselves as social entrepreneurs and identify with a community of peers. Our findings indicate that the coworking experience provided entrepreneurs, each of which with their distinctive background, with both a common denominator to define themselves, and a mode for inter-individual interactions within a shared space. These two elements combined led coworkers to participate in building a community of "hybrid" entrepreneurs, especially in the early years of the coworking space during which this entrepreneurial mode was nascent.

\section{Identifying with peers}

First, joining together with different backgrounds, the entrepreneurs mentioned that the coworking space helped them find common ground and gather around shared values and practices. Despite their different experiences with the social and/or commercial logics, all types of entrepreneurs identified each other as peers and form a community under the common banner of social entrepreneurship. Numerous coworkers explained how joining La Ruche had helped them give meaning to their project, identify with social entrepreneurship as their distinctive venturing mode, and break with isolation:

Being at La Ruche [gives] the feeling that you belong to a community that is built upon shared values and that is moving in the same direction [...]. Being surrounded by people who share the same desire to promote alternatives also helps to validate what you're doing and not just leave you to follow your instincts. (Sabine, forager bee, 2011)

Entrepreneurs who were more familiar with one the logics at play, i.e. nurse bees and drone bees, were reassured to see that their core logic had a central place, while at the same time feeling attracted by the opportunity to combine this core logic with the other logic they came 
to discover. To ensure the desired affiliation of the entrepreneurs with both logics, the staff of La Ruche had an important role in the recruitment process.

Clearly there is something that is common to all entrepreneurs here, because you believe in your project, it's typically entrepreneurial, but in addition it is social entrepreneurship so there is meaning [...], you believe in a project, in a way of seeing the world, in a way where you can participate in building a better world. It relates to your identity, the meaning you give to your life, well, it's super strong, probably more than in other entrepreneurial projects that are more rational. (Emma, nurse bee, 2019)

The filters were clear. If you didn't have the intent to build a credible business model, you wouldn't be accepted. And this was clearly accepted. [...] And then you had to demonstrate your orientation toward social innovation, your willingness to somehow change the world. [...] The people who came were those who had these two dimensions and identified as social entrepreneurs (Amaury, former staff member, 2019)

As coworkers recognized each other as peers, they could more easily take advantage of their differences to help and stimulate each other, further building the community of social entrepreneurs.

It's a space that represents a diversity of social entrepreneurial approaches and where the interactions allow you to cross into other areas, to move beyond your own work habits. [...] Through listening to other entrepreneurs, I have discovered a lot of new things outside of my line of business. (Patience, nurse bee, 2011)

The genius of the place was really to bring together people who were a bit isolated. Together we are stronger. There were many different projects, entrepreneurs with different backgrounds, different ages, different trajectories, and so on. [...] We really had a fairly wide range of sectors and activities. It was really nice! (Samuel, newbee, 2019)

There were different types of structures, some more business-oriented and others more associative, but always with a clear societal goal (Jacques-Yves, drone bee, 2019)

The exposition to diversity thus included both the plurality of sectors in which the entrepreneurs were active and the diversity of organizational vehicles adopted. Such vehicles often varied in function of the entrepreneurs' background: although the differences were not clear-cut, "nurse 
bees" were more present among those adopting a non-profit, associative form, whereas "drone bees" and "forager bees" tended to favour commercial forms (as incorporated business or sole entrepreneurs). While they appreciated to meet entrepreneurs with different backgrounds, certain drone bees felt different from the others, in particular nurse bees and newbees which they often perceived as too idealistic, and thus tended to favour interactions with entrepreneurs having a similar background.

We joined together [among "drone bees"] because we were the ones who had done something else before, who had known, in quotes, "the real life", who built our desires on practice and not on theory, because we had been in companies where we were being fattened, $[\ldots]$ where there was pressure and we wanted to do something else. And this is clearly different from the other categories [of entrepreneurs]. [...] Without consciously wanting to, we reformed in groups. (Corentin, drone bee, 2019)

Overall, despite some concerns regarding the management of such diversity, most interviewees viewed diversity in terms of complementary features and opportunities for mutual advice and stimulation in the context of an emerging community or peers.

\section{Building ties in a shared space}

Recognizing each other as peers and identifying themselves under the common umbrella of social entrepreneurship, entrepreneurs across the different profiles emphasized how interacting with like-minded entrepreneurs acted as a strong source of inspiration and motivation to engage and persevere in their entrepreneurial journey:

We shouldn't minimize mutual support. When you have downs and you realize the neighbor has successfully overcome the same type of down before, it's great! In social entrepreneurship, as you try to tackle a severe societal problem, you inevitably develop resent with regard to the government and business sectors who don't listen to you [...]. So joining a place where you can meet with others and say "yes, let's change the world", is a strong source of motivation. (Javier, forager bee, 2011)

The configuration of the shared space as well as the meeting opportunities both formal (e.g. events) and informal were acknowledged to favour interactions, although in many cases entrepreneurs, drone bees in particular, emphasized that sharing a common space was also challenging for working in a professional way. Several entrepreneurs explained how, after 
leaving the space, they reproduced some of its features, either in there venture headquarters or, interestingly in some cases, in another space shared with other ventures.

It's great to share a common place in which we feel at home, we behave here as if we were at home. We maintain the space as our common good [...]. It's an interesting work process. (Sabine, forager bee, 2011)

All in all people are here to work. We can discuss and exchange in the kitchen, ok, this is nice and may help us find novel ideas and be innovative. But we also need to be able to work, let's be realistic. (Bryce, drone bee, 2011)

Inspired and motivated by the community, and investing in the shared space, the interactions developed in a way that went beyond the type of business relationships that might be expected from gathering entrepreneurs, and led to strong connections sharing similarities with family ties.

It was a community. [...] It was equivalent to a family. Some people who for some reason had to leave said: "but I will never find again what I found in La Ruche, in terms of human connections and atmosphere.” (Perceval, forager bee, 2019)

Such ambition, however, was put under pressure as the coworking space grew between 2010 and 2013, leading certain coworkers to feel frustration because it had become difficult to know all the other projects:

We've come here to work together with others and it takes 6 months to discover that the guy in front of you does exactly what you'd like to do, or would be your ideal partner. [...] This means that there's a problem, it doesn't work because the goal of La Ruche is precisely to enable these connections. (Philippe, nurse bee, 2011)

Over time, such growth led to replicating the project through creating other coworking spaces in other regions of France. This enabled to maintain relatively small settings with strong familylike interactions. Interestingly, in many cases such interactions continued even after leaving the coworking space, as several former coworkers explained:

Working together in the same space creates bonds that are so strong that when people leave the space, they remain connected. (Dominique, staff member, 2019) 
In brief, overall, the entrepreneurs with different backgrounds felt that interacting with other entrepreneurs in the coworking experience led them to identify themselves with social entrepreneurship as a hybrid venturing mode. In particular, it enabled them to join a community of peer entrepreneurs recognizing themselves under the same banner despite their different backgrounds. Although working with diverse entrepreneurs and sharing the same space had its challenges, all the interviewed entrepreneurs underlined how this community-building role mattered much as they engaged in a relatively uncommon entrepreneurial mode.

\section{Collectively experimenting with hybridity}

Beyond their individual commitment to joining the social entrepreneurship community, entrepreneurs primarily joined the coworking space to develop their own ventures. Unlike spaces promoting entrepreneurship in general, however, specific to La Ruche was that most entrepreneurs were not familiar with hybrid venturing before joining the space - even the "forager bees" had limited experience. Thus, being at the coworking space enabled the wouldbe social entrepreneurs to collectively learn about how to conciliate social and commercial logics and experiment with such conciliation in the context of their hybrid venture. Interestingly, the coworking space itself, as a social entrepreneurial project, was a complimentary site from which entrepreneurs could learn and test hybrid venturing.

\section{Developing projects as hybrid ventures}

First, all entrepreneurs valued the mutual support that they provided to each other. Several entrepreneurs mentioned such mutual support as a state of mind inherent in the community more than as a system in which experts would teach novices. Even newbees reported that they felt valued when challenging the projects of more experienced entrepreneurs.

If you accept that your knowledge inside La Ruche is shared freely with others, you are part of the community. And all the people who join La Ruche today have the feeling that they are participating in something bigger, that their knowledge is available to others. [...] We create a space for professional knowledge to be shared freely. It's like the Wikipedia of entrepreneurial experience. (Bob, staff member, 2019) 
At La Ruche I've received much help about many things that are useful for my project, expertise regarding eco-construction, hotel design and architecture, organic material, etc. (Sabine, forager bee, 2011)

More specifically, the learning and experimentation in the context of the coworkers' ventures concerned both the social and commercial dimensions. The role of the coworkers, whether entrepreneurs, intrapreneurs, or staff, in helping reinforce the social impact of the ventures and their adequacy in addressing societal challenges, was unanimously acknowledged.

What makes the difference is this willingness of people to ask themselves 'what is my social and environmental impact?' It's permanent and you can't find this outside of La Ruche. At [La Ruche], there's always someone to remind us of this [impact], which we could lose sight of when day after day we're dealing with the numbers and looking for money. (Catherine, drone bee, 2013)

It's stimulating to be with people who promote social innovation. I draw inspiration from their way of reading the world and solving problems. (Samuel, newbee, 2011)

Nurse bees in particular appeared as the "guardians" of this dimension and most of them delivered advice and shared their experience during the formal events as well as during informal meetings. Such expertise was particularly appreciated by newbees who constructed their social entrepreneurial project, and by drone bees who were already familiar with the business dimension and came to La Ruche specifically to integrate a genuine social mission into their ventures.

Similarly, entrepreneurs valued the opportunity to reinforce the commercial logic within their ventures. This was, logically, valued by nurse bees and newbees who precisely lacked familiarity with this dimension.

I really liked the possibility of having access to a certain number of business skills that are useful when you put together a project. Relying on the available skills is interesting. It allows you to go faster, it boosts ideas, and challenges you as an entrepreneur. (Greta, nurse bee, 2019)

Drone bees were particularly committed to sharing their commercial expertise with nurse bees and newbees. Although some business training was organized by the staff, several drone bees 
found that the support in terms of business model development was insufficient for the entrepreneurs less familiar with the commercial logic. They suggested that the staff and the other entrepreneurs were unable to provide such support and focused too much on social impact, leading them to take over that role in an informal way, as observed in several instances.

It's hard for La Ruche members to be lucid about the business relevance of the solutions they bring, let alone build a viable business model. [...] At the end of the day, people wonder 'what impact have I really had?' (Bryce, drone bee, 2011)

Over time, as "drone bees" became much more involved in the leadership of the coworking space, the opportunities to share business expertise became more formalized and systematic, which was highly valued by the entrepreneurs lacking such background (nurse bees and newbees). For example, these entrepreneurs were instrumental in the creation of the "social innovation factory", an internal project recently launched at La Ruche to formally incubate some emergent hybrid ventures.

Beyond reinforcing the social and commercial logics taken in isolation, most importantly, entrepreneurs reported how the coworking experience had helped them conciliate both logics in the context of a hybrid venture. This involved adopting a hybridity mindset as well as developing concrete methods to build a business model with social impact. Certain entrepreneurs, particularly drone bees, were keen to revisit their previous business expertise and reorient it to achieve social goals. Nurse bees, on the other hand, while maintaining their orientation toward pursuing a social mission, became more comfortable with tools and mindset of the commercial logic.

To set up a social venture, it's important to acquire the fundamentals of designing a business model, having money flow in and find clients. The innovation spark comes from the knowledge of plural logics. (Bryce, drone bee, 2019)

What I've found interesting at La Ruche is that we leave the binary thinking about profit or not-for-profit, good or evil. Here there's a dialogue, we're no longer afraid of success so it frees us from the taboo of making profit and shifts [the discussion] towards 'what do we do with the profit?' This brings new ideas on how to make money [...] and have it circulating in a different way. (Garance, nurse bee, 2013) 
I don't run the business in the way I did previously. But I maintained a part of my previous self that is an asset too. I think especially of commercial aggressiveness where we use what we learned before, but this time not in the benefit of shareholders but for the sake of a higher cause. [...] Now it is for the creation of employment that I fight. So, it's a little different, but on the other hand, the know-how, the fight, I brought it from my previous experience. (Corentin, drone bee, 2019)

Such combination, however, was difficult to achieve and several coworkers suggested that in the early years La Ruche had focused too much on helping entrepreneurs generate social impact. With the development of the project, the importance of developing a solid business model was emphasized in parallel with the need to generate social impact, leading the coworking space as a venture in itself to endorse hybridity, as developed in the next section.

\section{Developing the coworking space as a hybrid venture}

From the beginning, La Ruche itself aimed to function as a hybrid venture, relying on the commercial revenues (membership fees) to achieve its mission of supporting social entrepreneurs. Entrepreneurs were closely involved in the effort to develop the coworking space as a socially entrepreneurial, hybrid model. This involved developing both the social and commercial logics of the coworking space and building governance mechanisms to ensure their conciliation. However, in the early years, the entrepreneurs were very critical regarding the management of each of these logics, showing the difficulty of "walking the talk" at the level of the coworking space.

On the business side, the critiques concerned the difficulty to reach a financially sustainable model but also to maintain basic business functions such as a proper telephone system. These critiques came from the four types of entrepreneurs but in particular from the drone bees. However they were not strong enough to constitute grounds for leaving the place, and they were not regarded as major issues retrospectively.

We should have endorsed the costs [...]. We lacked business reasoning. That's often the problem of associative models where more can be accepted than in a classical [business] model. But it shouldn't go too far. (Jeoffrey, drone bee, 2019) 
We have a big phone problem here. In my former business centre, we would have screamed! We would have had a maximum of half a day of telephone problems. We've had problems for ages here, though. There is a DIY spirit that is part of the folklore and that we accept when we arrive. (Jeoffrey, drone bee, 2011)

Regarding the social mission of the coworking space, this dimension was surprisingly questioned by several entrepreneurs across the different profiles. While the added-value of La Ruche for improving the social impact of the ventures was widely acknowledged (see above), there was more skepticism regarding the social focus at the level of the coworking space itself, for example its tariffs, HR practices or legal form.

There are few permanent employees here, there are many interns, it's not really sustainable development. That's the limit: aspiring to change the world while trying to bring money in is hard. (Catherine, drone bee, 2011)

It looks alternative but it's not really. True social entrepreneurs would already have a cooperative. Same for the environmental aspect. [...] What is a lacking a bit is for the community to think about itself, its environmental impact, its social impact. (Perceval, forager bee, 2011)

Despite some disappointment, many entrepreneurs expressed that witnessing these shortcomings was very useful as it enabled them to understand how not to repeat the same mistakes. This was also observed for the governance of the coworking space, in which the entrepreneurs could participate and thus experiment with governance methods meant to facilitate the combination of social and commercial logics. The involvement in and experimentation with hybrid governance modes generated mixed feelings, especially forager and drone bees who were particularly demanding with regard to the development of a hybrid and inclusive governance.

They are very much in the theory of participative democracy, $[\ldots]$ more as a stance than as something sincere. If we really want to give people power, we give them. We don't pretend and then continue business as usual. (Barthelemy, drone bee, 2011) 
We built a system that made us think, that challenged us, that helped us move forward. We took all the decisions collectively. Afterwards it was up to us to see what we wanted to do with it for our projects. This was La Ruche for me. (Sabine, forager bee, 2019)

As illustrated in the last quote, in the 2019 interviews, several entrepreneurs expressed that they appreciated the opportunity to learn from the mistakes and shortcomings of the coworking space to develop better processes in the context of their own ventures. Overall, the entrepreneurs used the coworking space experience to collectively learn about and experiment with hybrid venturing both through their own venture and at the level of the coworking space itself. The latter was sometimes seen as problematic during the coworking experience but benefitted them through providing an example of how hybrid venturing should or should not be conducted.

\section{Collectively institutionalizing hybrid venturing}

\section{Connecting with the broader ecosystem}

Finally, besides forming a community of peers and collectively experimenting with hybrid venturing, the entrepreneurs suggested that they had contributed to institutionalizing hybrid venturing through the coworking space, which had positively influenced their identification with and commitment to this entrepreneurial mode. This involved, first, developing collaborations within and outside of the emerging social entrepreneurship ecosystem. Second, through building visibility and credibility for their ventures, coworkers felt that across their various backgrounds they had contributed to building their collective legitimacy as hybrid entrepreneurs.

\section{Developing collaborations}

The coworking space acted as a catalyzer and offered numerous opportunities for entrepreneurs to work together and create critical mass. Beyond the inter-individual exchanges described in the first community-building dimension, more formal collaborations emerged among the ventures in a way that was sometimes unexpected but unanimously acknowledged by the different profiles of coworkers. While there were obviously collaborations between entrepreneurs of the same type, we observed numerous collaborations gathering different types and enabling to exploit complementarities. 
Since as a business we didn't have much expertise in training programs [for low-skilled workers] and [forager bee entrepreneur] had already developed these modules, they helped us to design trainings [...]. And they relayed the news in their networks. This is a precise example of what I couldn't have done if [forager bee entrepreneur] wasn't working besides me and if we didn't see each other so regularly (Bryce, drone bee, 2011)

Beyond the opportunities for collaboration among the coworkers' ventures, the interactions within and visibility of the coworking space also offered numerous opportunities to connect with external partners such as businesses, governments, and the media. Sometimes, these external connections emerged from internal collaborations, for example in the context of jointly answering calls for tender.

I was able to find contacts for my business because there are complementary organisations [at La Ruche] which had networks that might interest me [...]. We answered a call for tender with two other La Ruche organisations. As there were three of us, we were able to put in a bid and be good. (Perceval, forager bee, 2011)

The experience at La Ruche allowed us to interact with some major actors in the field, which we wouldn't have had if we had each remained working in our little corner. (Cain, drone bee, 2019)

Beyond bringing immediate benefits to their ventures, the collaborations also enabled entrepreneurs to participate in building the social entrepreneurship ecosystem and to build legitimacy for themselves as well as for hybrid ventures in general.

\section{Building legitimacy as hybrid entrepreneurs}

Finally, the entrepreneurs emphasized how participating in La Ruche enabled them to build legitimacy as hybrid entrepreneurs in the eyes of a number of constituents such as public authorities, the media, the business and entrepreneurial communities, and more broadly the general public. Our findings suggest that the legitimation of the ventures, of the coworking space and of hybrid venturing in general went hand in hand and enabled entrepreneurs to make their ventures more visible and credible. Drone bees, in particular, were particularly eager to be 
acknowledged in their pursuit of a social mission, becoming legitimate as "social" entrepreneurs. Nurse bees, on the other hand, appreciated that they were recognized as genuine entrepreneurs. For newbees, finally, being accepted at La Ruche was a first sign of credibility that could be displayed to the outer world.

There was a social dimension in my project, but I didn't feel legitimate from a social standpoint because I was coming from the business world, a [software company] that had nothing to do with social entrepreneurship. I joined La Ruche with stars in my eyes and I learned a lot from interacting with other entrepreneurs [...], it reassured me about my capacity to be a coherent and legitimate actor in this environment (Corentin, drone bee, 2019)

They [partners] now understand that in order to solve social problems, we use business activities. Once they've understood this it means a lot $[\ldots]$, we were categorized, identified within a movement. (nurse bee, 2011)

The fact of being here gives credibility. It adds something and reflects specific values. And for the clients who know [the coworking space], they tell me 'ok you're a startup, but you've been accepted at La Ruche'. (Simon, newbee, 2011)

Success stories were diffused through La Ruche and helped inspire emerging ventures and become credible for external staekholders, especially in the early years where both the ventures and the ecosystem were under construction and faced the challenge of building visibility and legitimacy.

It was not easy to engage in social entrepreneurship in France. So it was really useful to be in a structure where there was such mutual support, where success stories were shared and where the sector could become more visible. (Cain, forager bee, 2019)

It is true that among the ventures present at La Ruche there are a lot of stars, stars in the sense of "companies that have brought something to the market in terms of social business in the broad sense". (Jeoffrey, drone bee, 2011)

The role of La Ruche in advancing the recognition of social entrepreneurship not only opened new business opportunities, but also contributed to connecting with public authorities and civil society actors, and participating in transforming the broader economic system. 
Being at La Ruche gives us credibility. It is quite well known in the sustainable development community. It adds something, it signals values. (Catherine, drone bee, 2011)

In brief, the third dimension of the coworking space experience was the entrepreneurs' participation in institutionalizing hybrid venturing. This role was unanimously acknowledged across all entrepreneurial types. In a context in which the field of social entrepreneurship was under construction, the coworking experience was instrumental to help entrepreneurs develop collaborations in and across the ecosystem and, through their interactions, build their visibility and credibility as hybrid entrepreneurs.

\section{Discussion and conclusion}

The goal of this paper was to explore how interacting in a coworking space enabled entrepreneurs to embrace hybrid venturing (in this case social entrepreneurship). Three main avenues emerged through which entrepreneurs developed familiarity with and commitment to plural logics in the context of their emerging venture. First, within the coworking space, entrepreneurs joined a community of like-minded entrepreneurs and developed family-like interactions with entrepreneurs from different logic backgrounds in a way that increased their motivation for and identification with hybrid venturing. Second, the coworking space enabled coworkers to learn about and experiment with hybrid venturing, both through mutually enriching their ventures, and through the process of building the coworking space itself as a hybrid venture. Third, at a broader level, entrepreneurs participated in institutionalizing hybrid venturing, a process through which they developed collaborations in and outside of the coworking space, and gained sustained visibility and credibility as pioneering hybrid entrepreneurs.

As summarized in Table 4, the perceptions varied in function of the entrepreneurial types, defined based on the initial background of the entrepreneurs (familiarity with one, both or none of the social and commercial logics at play). Overall, entrepreneurs across the four types suggested that the coworking experience had helped them embrace hybrid venturing through building a community or peers and participating in institutionalizing social entrepreneurship. They nevertheless emphasized more limitations regarding the opportunity to experiment with 
hybridity at the level of their own ventures and even more at the level of the coworking space itself. This was particularly the case for entrepreneurs with a either a social background ("nurse bees") or a business background ("drone bees"). Nevertheless, they became increasingly involved in interacting to specifically teach their core logic to the other group, acquire their missing logic from that group, and integrate it into their venture. Entrepreneurs already familiar in conciliating social and commercial logics ("forager bees") used the coworking experience to consolidate their recent experience and integrate hybridity within their emerging entrepreneurial project. Together with the drone and nurse bees, they noted limitations and shortcoming in building the coworking space itself as a hybrid venture, however they took advantage of this experience to learn about how (not) to proceed when integrating social and commercial logics in their own ventures. Finally, entrepreneurs with no relevant experience with either logic ("newbees") started from a blank page and most clearly emphasized that the space contributed to forging their commitment and capacity to engage in a hybrid venturing project.

\section{Insert table 4 about here}

We suggest that these findings contribute to the literatures on hybridity, coworking spaces and social entrepreneurship. First, with regard to the literature on hybrid venturing and organizing, our findings bring insights on how hybridity may emerge from the interaction between peer entrepreneurs at the early stages of organizational creation beyond their ex-ante logic familiarity (Pache \& Santos, 2013a). We thus document how a relatively weakly structured peer-to-peer setting may enrich the individuals" “institutional biographies" towards higher hybridity (Bertels \& Lawrence, 2016; Lawrence et al., 2011). By doing so, this paper highlights an avenue for hybridizing entrepreneurs and their ventures that is different from other avenues documented in the literature. With regard to the examination of entrepreneurs' individual trajectories (e.g., Lee \& Battilana, 2013), our paper emphasizes the importance of collective dynamics whereby hybridity is experienced in a small group context in which entrepreneurs can then integrate insights from such dynamics into their individual ventures (whether identity, ideas, techniques, contacts etc.). Such group context differs from established hybrid organizations that position individuals in a hierarchy geared towards the pursuit of one single "hybrid" project and where the socialization into hybridity is thus much more structured (Battilana \& Dorado, 2010; Pache \& Santos, 2013b) and tolerates that certain individuals remain embedded in one dominant logic (Bertels \& Lawrence, 2016; Pache \& Santos, 2013a). 
Making hybrids work with non-hybrid individuals has been especially observed in so-called "structural hybrids" in which each logic is dealt with by a different unit, albeit with spaces for encounter and exchange (Ashforth \& Reingen, 2014; Perkmann et al., forthcoming). Similarly, the work on hybridity in the context of entrepreneurial teams shows how individuals may each remain rooted in one dominant logic and achieve hybridity through the combination of each individual's logic (Almandoz, 2012; Dufays \& Huybrechts, 2016). Our research, by contrast, documents the interface between individually-led ventures requiring "hybridized" entrepreneurs, and a collective interaction experience that enables these entrepreneurs to extend beyond their initial background and recognize themselves as, experiment with and participate in institutionalizing hybrid venturing. Extending previous work that suggests absence of logic familiarity ("tabula rasa") is preferable to ex-ante familiarity with one of the logics at play, we document how socialization may unfold in a peer-to-peer setting gathering entrepreneurs familiar with one, none but also both logics already. Such socialization into the logic(s) for which entrepreneurs have lower familiarity (Pache \& Santos, 2013a) is enabled by different features inherent in the coworking space (in terms of group composition and interaction, space, events etc.) and includes, beyond skills acquisition, identification, experimentation and institutionalization functions.

Our findings also extend the understanding of the collaboration between hybrids beyond the study of established organizations (Bergman, 2017; York et al., 2016) to highlight the importance of collaboration when hybrid ventures are under construction. As most collaborations that entrepreneurs develop with peer entrepreneurs and with other stakeholders last beyond their stay at the coworking space, collaborations at the interpersonal and interventure level play an important role in the sustained hybridity of the social entrepreneurs and of their ventures (McMullen, 2018). Finally, our research also emphasizes the role of physical space in the development of hybrid ventures. Extant research has theorized the existence of “interstitial spaces" (Furnari, 2014) where new combinations of logics from different fields can be experimented with and diffused to existing or new "hybrid" fields (York et al., 2016). However, the way in which these spaces offer opportunities for individuals, in this case social entrepreneurs, to "hybridize" and integrate such process into their ventures, has not received much attention so far.

Second, related to the previous point, we extend the emerging literature on collaborative spaces and more specifically coworking spaces (Bouncken \& Reuschl, 2018; Garrett et al., 2017). We 
document how the opportunities offered by such spaces embody a particular importance in the context of hybrid venturing, where the goal is not only to gather workers, but to socialize wouldbe entrepreneurs into a novel entrepreneurial mode combining plural institutional logics. In this context, our findings extend the community-building role that has been highlighted in the coworking space literature (Bouncken \& Reuschl, 2018; Garrett et al., 2017) to integrate a function through which entrepreneurs collectively build a common "hybrid" identity (Wry \& York, 2017) backed by strong values and practices (Miller, Grimes, McMullen, \& Vogus, 2012). We suggest that the coworking space configuration and the peer-to-peer interactions enable entrepreneurs to "cross-fertilize" and embrace hybridity in an informal, bottom-up manner. These interactions in a shared space, leading to the emergence of a localized community, are of particular importance in the case of hybrid venturing, which lacks recognition and established venturing patterns (Huybrechts \& Haugh, 2018; McMullen, 2018). While the creation of a strong community may be similarly observed in other structures supporting hybrid venturing, typically incubators and accelerators (Giudici et al., forthcoming; Ometto et al., forthcoming), our findings document the bottom-up dynamics through which entrepreneurs identify as peers and engage with hybridity in a relatively spontaneous and unstructured way.

The focus on hybrid venturing also extends our understanding of the "organizationality" of coworking spaces, i.e. their function of organizing workers albeit without hierarchical links (Blagoev et al., 2019). Indeed, when the entrepreneurial form of coworkers' ventures is under construction, the coworking space is not only a space for gathering and exchanging, but also a space for experimenting with this new entrepreneurial mode through building the entrepreneurs' projects, as well as the coworking space itself, as novel (in this case hybrid) ventures (Battilana \& Dorado, 2010). For the former, our findings show that the entrepreneurs searched, through the coworking space experience, to integrate the logics that they lacked most. In particular, the entrepreneurs with a business background sought to improve their social impact orientation, while those with a more social background were keen to develop their business skills, albeit not always successfully. Previous work has shown how such "compensation" happens when structural elements corresponding to the other logic are deliberately adopted to seek legitimacy (Pache \& Santos, 2013b), however we extend this view to the entrepreneurial level by showing how, thanks to peer-to-peer interactions, individual entrepreneurs hybridize their profile and skills while creating their ventures. 
For the coworking space as a venture in itself, our findings show that the entrepreneurs valued the opportunity of developing it as a hybrid venture in coherence with what they built for their own ventures, similar to, for example, social entrepreneurship accelerators (Giudici et al., forthcoming). However, building the coworking space as a viable, professional business at the same time as ensuring a consistent social mission appeared as a challenge. While the governance of hybrid organizations is intrinsically challenging because of the need to maintain the balance between their dual missions (Ebrahim et al., 2014), in this case the coordination among numerous members increased the complexity and caused frustrations. However, even these frustrations were seen by most entrepreneurs as learning opportunities that could be inspiring for developing the governance of their ventures and ensure hybridity in a long-lasting way (Battilana \& Dorado, 2010).

Our study also emphasizes a less commented role of coworking spaces, resulting from the efforts of the entrepreneurs to diffuse and legitimize hybrid venturing (in this case social entrepreneurship). This role extends beyond building an ecosystem of ventures and partners (Bouncken \& Reuschl, 2018; Jakonen, Kivinen, Salovaara, \& Hirkman, 2017). Indeed, when building the visibility and credibility of their venturing mode through the coworking space, entrepreneurs catalyze the institutionalization of hybrid venturing and thus act as institutional entrepreneurs in a small group setting (Dorado, 2013). This role is not exclusive, as other actors are involved in advancing the recognition of social entrepreneurship (Nicholls, 2010). Nevertheless, the coworking space enabled emerging entrepreneurs to participate in this collective institutionalization effort even with little resources or experience in this sector (Dorado, 2013), which was unanimously acknowledged by coworkers, both in itself and through the benefits in terms of recognition and advancement of their ventures.

Finally, the research also contributes to the literature and practice of social entrepreneurship. Much effort and money have been invested to support nascent social enterprises through incubators, competitions and networking schemes (Meyskens et al., 2010; Nicholls, 2010). While this may be of value, coworking spaces appear as an alternative, more bottom-up and probably less costly initiative mainly based on providing space (in all the meanings of the term) in which a community of social entrepreneurs can emerge and collectively learn how to build ventures that conciliate social and commercial goals (Mitzinneck \& Besharov, forthcoming; Montgomery, Dacin, \& Dacin, 2012). Our study emphasizes the added-value of gathering entrepreneurs with different backgrounds, which enables mutual support and advice in a way 
that maximizes complementarity (Dufays, 2019). While in our setting such diversity was not purposefully achieved, it could be relevant to consider how entrepreneurs can be best recruited and socialized so as to take advantage of these entrepreneurs' varied profiles.

Our study suffers from a number of limitations, each of which provides opportunities for future research. First, the findings are based on a single case study and are thus contingent on its context, i.e. the French social entrepreneurship ecosystem. However, to examine how a coworking space led entrepreneurs to develop hybrid ventures, an established space with a focus on hybrid venturing was necessary, which led to choose a pioneering, emblematic case. To generalize and refine the findings, future research could adopt a comparative approach, contrasting different places and/or creation periods to highlight how the potential to stimulate a particular entrepreneurial mode may vary across settings. For example, coworking spaces that are more recent and/or located in regions where hybrid venturing is more institutionalized than in our research are likely to play a different role, probably less focused on community-building and institutionalization and more on concrete avenues to help coworkers experiment with and learn about hybrid venturing. Second, our research focused on two main periods in the evolution of the ventures, and relied on ex-post rationalization to understand the contribution of the coworking experience. Therefore, attribution biases may intervene when entrepreneurs try to make sense of their experiences and understand its added-value among other possible contributing factors. Future studies could use a richer array of methods, including focus groups, or life trajectory analyses, to elucidate how a coworking space experience may (or not) help embed hybridity into the profiles and ventures of the entrepreneurs. An events-based approach (Hussenot \& Missonier, 2015) could also be used to understand how entrepreneurs experience key events while participating in the coworking space. Despite these limitations, this paper offers new insights on how hybrid venturing can be stimulated collectively, in particular in coworking spaces and other increasingly widespread collaborative settings.

\section{References}

Aldrich, H. E., \& Fiol, C. M. (1994). Fools rush in? The institutional context of industry creation. Organization Studies, 19(4), 645-670.

Allen, D. N., \& McCluskey, R. (1990). Structure, Policy, Services, and Performance in the Business Incubator Industry. Entrepreneurship: Theory \& Practice, 15(2), 61-77. 
Almandoz, J. (2012). Arriving at the starting line: The impact of community and financial logics on new banking ventures. Academy of Management Journal, 55(6), 1381-1406.

Ashforth, B. E., \& Reingen, P. H. (2014). Functions of Dysfunction: Managing the Dynamics of an Organizational Duality in a Natural Food Cooperative. Administrative Science Quarterly, 59(3), 474-516. doi:10.1177/0001839214537811

Autio, E., Nambisan, S., Thomas, L. D. W., \& Wright, M. (2018). Digital affordances, spatial affordances, and the genesis of entrepreneurial ecosystems. Strategic Entrepreneurship Journal, 12(1), 72-95. doi:10.1002/sej.1266

Battilana, J., \& Dorado, S. (2010). Building sustainable hybrid organizations: The case of commercial microfinance organizations. Academy of Management Journal, 53(6), 14191440 .

Battilana, J., \& Lee, M. (2014). Advancing research on hybrid organizing: Insights from the study of social enterprises. The Academy of Management Annals, 8(1), 397-441. doi:10.1080/19416520.2014.893615

Battilana, J., Sengul, M., Pache, A.-C., \& Model, J. (2015). Harnessing productive tensions in hybrid organizations: The case of work integration social enterprises. Academy of Management Journal, 58(6), 1658-1685. doi:10.5465/amj.2013.0903

Bergman, B. (2017). Agents of Change? An Inter-Organizational Research Agenda on Hybrid New Ventures. In A. C. Corbett \& J. A. Katz (Eds.), Hybrid Ventures (Vol. 19, pp. 219232). New York: Emerald.

Bertels, S., \& Lawrence, T. B. (2016). Organizational responses to institutional complexity stemming from emerging logics: The role of individuals. Strategic Organization, 14(4), 336-372. doi:10.1177/1476127016641726

Besharov, M. L., \& Smith, W. K. (2014). Multiple institutional logics in organizations: Explaining their varied nature and implications. Academy of Management Review, 39(3), 364-381. doi:10.5465/amr.2011.0431

Blagoev, B., Costas, J., \& Kärreman, D. (2019). 'We are all herd animals': Community and organizationality in coworking spaces. Organization, 26(6), 894-916. doi:10.1177/1350508418821008

Bouncken, R., \& Reuschl, A. (2018). Coworking-spaces: how a phenomenon of the sharing economy builds a novel trend for the workplace and for entrepreneurship. Review of Managerial Science, 12(1), 317.

Brown, J. (2017). Curating the "Third Place"? Coworking and the mediation of creativity. Geoforum, 82, 112-126. doi:10.1016/j.geoforum.2017.04.006 
Bruneel, J., Ratinho, T., Clarysse, B., \& Groen, A. (2012). The Evolution of Business Incubators: Comparing demand and supply of business incubation services across different incubator generations. Technovation, 32(2), 110-121. doi:https://doi.org/10.1016/j.technovation.2011.11.003

Butcher, T. (2018). Learning everyday entrepreneurial practices through coworking. Management Learning, 49(3), 327-345. doi:10.1177/1350507618757088

Dorado, S. (2013). Small Groups as Context for Institutional Entrepreneurship: An Exploration of the Emergence of Commercial Microfinance in Bolivia. Organization Studies, 34(4), 533-557. doi:10.1177/0170840612470255

Dufays, F. (2019). Exploring the drivers of tensions in social innovation management in the context of social entrepreneurial teams. Management Decision, 57(6), 1344-1361.

Dufays, F., \& Huybrechts, B. (2016). Where do hybrids come from? Entrepreneurial team heterogeneity as an avenue for the emergence of hybrid organizations. International Small Business Journal, 34(6), 777-796. doi:10.1177/0266242615585152

Durante, G., \& Turvani, M. (2018). Coworking, the Sharing Economy, and the City: Which Role for the 'Coworking Entrepreneur'? Urban Science, 2(3), 83.

Ebbers, J. J. (2014). Networking Behavior and Contracting Relationships among Entrepreneurs in Business Incubators. Entrepreneurship Theory and Practice, 38(5), 123. doi:10.1111/etap. 12032

Ebrahim, A., Battilana, J., \& Mair, J. (2014). The governance of social enterprises: Mission drift and accountability challenges in hybrid organizations. Research in Organizational Behavior, 34, 81-100.

Eisenhardt, K. M. (1989). Building theories from case study research. Academy of Management Reviw, 14(4), 532-550.

Fabbri, J. (2016). Unplugged - "Place as spatio-temporal events": Empirical evidence from everyday life in a coworking space. [Unplugged - "Place as spatio-temporal events": Empirical evidence from everyday life in a coworking space].M@n@gement, 19(4), 353-361. doi:10.3917/mana.194.0353

Fabbri, J., \& Charue-Duboc, F. (2013). Un modèle d'accompagnement entrepreneurial fondé sur des apprentissages au sein d'un collectif d'entrepreneurs : le cas de La Ruche. Management International, 17, 86-99.

Furnari, S. (2014). Interstitial Spaces: Microinteraction Settings and the Genesis of New Practices Between Institutional Fields. Academy of Management Review, 39(4), 439462. doi:10.5465/amr.2012.0045 
Fuzi, A. (2015). Co-working spaces for promoting entrepreneurship in sparse regions: the case of South Wales. Regional Studies, Regional Science, 2, 462-469.

Gandini, A. (2015). The rise of coworking spaces: A literature review. Ephemera, 15(1), 193205.

Garrett, L. E., Spreitzer, G. M., \& Bacevice, P. A. (2017). Co-constructing a Sense of Community at Work: The Emergence of Community in Coworking Spaces. Organization Studies, 38(6), 821-842. doi:10.1177/0170840616685354

Gerdenitsch, C., Scheel, T. E., Andorfer, J., \& Korunka, C. (2016). Coworking Spaces: A Source of Social Support for Independent Professionals. Frontiers in Psychology, 7(581). doi:10.3389/fpsyg.2016.00581

Gioia, D. A., Corley, K. G., \& Hamilton, A. L. (2013). Seeking qualitative rigor in inductive research: Notes on the Gioia methodology. Organizational Research Methods, 16(1), 15-31. doi:10.1177/1094428112452151

Giudici, A., Combs, J. G., Cannatelli, B. L., \& Smith, B. R. (forthcoming). Successful Scaling in Social Franchising: The Case of Impact Hub. Entrepreneurship: Theory and Practice. doi:10.1177/1042258718801593

Grimes, M., Williams, T. A., \& Zhao, E. Y. (forthcoming). Anchors Aweigh: The Sources, Variety, and Challenges of Mission Drift. Academy of Management Review, forthcoming. doi:10.5465/amr.2017.0254

Hackett, S. M., \& Dilts, D. M. (2004). A Systematic Review of Business Incubation Research. The Journal of Technology Transfer, 29(1), 55-82. doi:10.1023/B:JOTT.0000011181.11952.0f

Huybrechts, B., \& Haugh, H. (2018). The Roles of Networks in Institutionalizing New Hybrid Organizational Forms: Insights from the European Renewable Energy Cooperative Network. Organization Studies, 39(8), 1085-1108.

Jakonen, M., Kivinen, N., Salovaara, P., \& Hirkman, P. (2017). Towards an Economy of Encounters? A critical study of affectual assemblages in coworking. Scandinavian Journal of Management, 33(4), 235-242. doi:https://doi.org/10.1016/j.scaman.2017.10.003

Lawrence, T., Suddaby, R., \& Leca, B. (2011). Institutional Work: Refocusing Institutional Studies of Organization. Journal of Management Inquiry, 20(1), 52-58. doi:10.1177/1056492610387222

Lee, M., \& Battilana, J. (2013). How the Zebra Got its Stripes: Imprinting of Individuals and Hybrid Social Ventures. Harvard Business School Organizational Behavior Unit Working Paper, 14(5). 
Lounsbury, M. (2002). Institutional transformation and status mobility: the professionalization of the field of finance. Academy of Management Journal, 45, 255266.

McMullen, J. S. (2018). Organizational hybrids as biological hybrids: Insights for research on the relationship between social enterprise and the entrepreneurial ecosystem. Journal of Business Venturing, 33(5), 575-590. doi:10.1016/j.jbusvent.2018.06.001

Meyskens, M., Robb-Post, C., Stamp, J. A., Carsrud, A. L., \& Reynolds, P. D. (2010). Social Ventures from a Resource-Based Perspective: An Exploratory Study Assessing Global Ashoka Fellows. Entrepreneurship Theory and Practice, 34(4), 661-680. doi:10.1111/j.1540-6520.2010.00389.x

Miller, T. L., Grimes, M. G., McMullen, J. S., \& Vogus, T. J. (2012). Venturing for Others with Heart and Head: How Compassion Encourages Social Entrepreneurship. Academy of Management Review, 37(4), 616-640. doi:10.5465/amr.2010.0456

Mitev, N., de Vaujany, F.-X., Laniray, P., Bohas, A., \& Fabbri, J. (2018). Co-working Spaces, Collaborative Practices and Entrepreneurship. In K. Riemer, S. Schellhammer, \& M. Meinert (Eds.), Collaboration in the Digital Age. How Technology Enables Individuals, Teams and Businesses (pp. 15-44). Cham: Spring Publications.

Mitzinneck, B. C., \& Besharov, M. L. (forthcoming). Managing Value Tensions in Collective Social Entrepreneurship: The Role of Temporal, Structural, and Collaborative Compromise. Journal of Business Ethics. doi:10.1007/s10551-018-4048-2

Montgomery, A. W., Dacin, P. A., \& Dacin, M. T. (2012). Collective Social Entrepreneurship: Collaboratively Shaping Social Good. Journal of Business Ethics, 111(3), 375-388. doi:10.1007/s10551-012-1501-5

Murray, F. (2010). The Oncomouse That Roared: Hybrid Exchange Strategies as a Source of Distinction at the Boundary of Overlapping Institutions. American Journal of Sociology, 116(2), 341-388.

Nicholls, A. (2010). The Legitimacy of Social Entrepreneurship: Reflexive Isomorphism in a Pre-Paradigmatic Field. Entrepreneurship Theory and Practice, 34(4), 611-633. doi:10.1111/j.1540-6520.2010.00397.x

Ometto, M. P., Gegenhuber, T., Winter, J., \& Greenwood, R. (forthcoming). From Balancing Missions to Mission Drift: The Role of the Institutional Context, Spaces, and Compartmentalization in the Scaling of Social Enterprises. Business \& Society, O(0), 0007650318758329. doi:10.1177/0007650318758329

Pache, A.-C., \& Santos, F. (2013a). Embedded in Hybrid Contexts: How Individuals in Organizations Respond to Competing Institutional Logics. In F. Santos, L. Michael, \& B. Eva (Eds.), Institutional Logics in Action, Part B (Vol. 39 Part B, pp. 3-35): Emerald Group Publishing Limited. 
Pache, A.-C., \& Santos, F. (2013b). Inside the hybrid organization: Selective coupling as a response to conflicting institutional logics. Academy of Management Journal, 56(4), 972-1001. doi:10.5465/amj.2011.0405

Perkmann, M., McKelvey, M., \& Phillips, N. (forthcoming). Protecting Scientists from Gordon Gekko: How Organizations Use Hybrid Spaces to Engage with Multiple Institutional Logics. Organization Science. doi:10.1287/orsc.2018.1228

Phan, P. H., Siegel, D. S., \& Wright, M. (2005). Science parks and incubators: observations, synthesis and future research. Journal of Business Venturing, 20(2), 165-182. doi:https://doi.org/10.1016/j.jbusvent.2003.12.001

Ramus, T., \& Vaccaro, A. (2017). Stakeholders matter: How social enterprises address mission drift. Journal of Business Ethics, 143(2), 307-322.

Schwartz, M., \& Hornych, C. (2008). Specialization as strategy for business incubators: An assessment of the Central German Multimedia Center. Technovation, 28(7), 436-449. doi:https://doi.org/10.1016/j.technovation.2008.02.003

Shepherd, D. A., Williams, T. A., \& Zhao, E. Y. (forthcoming). A Framework for Exploring the Degree of Hybridity in Social Entrepreneurship. Academy of Management Perspectives. doi:10.5465/amp.2018.0013

Spedale, S., \& Watson, T. J. (2014). The emergence of entrepreneurial action: At the crossroads between institutional logics and individual life-orientation. International Small Business Journal, 32(7), 759-776. doi:10.1177/0266242613480376

Spinuzzi, C. (2012). Working Alone Together: Coworking as Emergent Collaborative Activity. Journal of Business and Technical Communication, 26(4), 399-441. doi:10.1177/1050651912444070

Thornton, P. H. (2004). Markets from Culture: Institutional Logics and Organizational Decisions in Higher Education Publishing. Stanford, CA: Stanford University Press.

Vidaillet, B., \& Bousalham, Y. (forthcoming). Coworking spaces as places where economic diversity can be articulated: Towards a theory of syntopia. Organization. doi:10.1177/1350508418794003

Wry, T., \& York, J. G. (2017). An identity-based approach to social enterprise. Academy of Management Review, 42(3), 437-460.

Yin, R. K. (2009). Case study research. Design and methods. Thousand Oaks: Sage.

York, J., Hargrave, T., \& Pacheco, D. (2016). Converging winds: Logic hybridization in the Colorado wind energy field. Academy of Management Journal, 59(2), 579-610. doi:10.5465/amj.2013.0657 
Table 1 - Interviews details

\begin{tabular}{|c|c|c|c|c|c|c|}
\hline $\begin{array}{c}\text { Entrepreneurial } \\
\text { status }\end{array}$ & Gender & Name & Membership & Category & $\begin{array}{c}\text { Formal } \\
\text { interview } \\
2010-2013\end{array}$ & $\begin{array}{c}\text { Formal } \\
\text { interview } \\
\text { 2018-2019 }\end{array}$ \\
\hline Intrapreneur & F & Patience & Full time & Nurse & $\mathrm{N}$ & $\mathrm{Y}$ \\
\hline Entrepreneur & M & Mikol & Full time & Drone & $\mathrm{N}$ & Y \\
\hline Entrepreneur & M & Samuel & Full time & Newbee & $\mathrm{N}$ & Y \\
\hline Entrepreneur & M & Bastien & Full time & Newbee & $\mathrm{N}$ & Y \\
\hline Entrepreneur & F & Emma & Member & Nurse & $\mathrm{N}$ & Y \\
\hline Entrepreneur & M & Pedro & Member & Drone & $\mathrm{N}$ & $\mathrm{Y}$ \\
\hline Entrepreneur & M & Flavien & Member & Newbee & $\mathrm{N}$ & Y \\
\hline Entrepreneur & M & Javier & Full time & Forager & $\mathrm{N}$ & $\mathrm{Y}$ \\
\hline Entrepreneur & M & Hamed & Full time & Forager & $\mathrm{N}$ & $\mathrm{Y}$ \\
\hline Entrepreneur & $\mathrm{F}$ & Greta & Full time & Nurse & $\mathrm{N}$ & $\mathrm{Y}$ \\
\hline Intrapreneur & $\mathrm{F}$ & Floriane & Full time & Newbee & $\mathrm{Y}$ & $\mathrm{Y}$ \\
\hline Entrepreneur & M & Jacques-Yves & Full time & Drone & Y & $\mathrm{Y}$ \\
\hline Entrepreneur & $\mathrm{F}$ & Sabine & Full time & Nurse & Y & Y \\
\hline Entrepreneur & M & Cain & Full time & Forager & Y & Y \\
\hline Entrepreneur & M & Pascual & Full time & Nurse & Y & Y \\
\hline Entrepreneur & M & Tanguy & Full time & Drone & Y & Y \\
\hline Entrepreneur & M & Nicolas & Full time & Drone & $\mathrm{Y}$ & $\mathrm{Y}$ \\
\hline Entrepreneur & M & Thiebaud & Part-time & Drone & $\mathrm{Y}$ & $\mathrm{Y}$ \\
\hline Entrepreneur & $\mathrm{F}$ & Garance & Part-time & Drone & Y & $\mathrm{Y}$ \\
\hline Entrepreneur & $\mathrm{F}$ & Daniele & Part-time & Drone & Y & $\mathrm{Y}$ \\
\hline Entrepreneur & M & Bryce & Full time & Drone & Y & $\mathrm{Y}$ \\
\hline Entrepreneur & $\mathrm{F}$ & Viviane & Full time & Drone & Y & $\mathrm{Y}$ \\
\hline Entrepreneur & M & Vivien & Full time & Drone & Y & $\mathrm{Y}$ \\
\hline Entrepreneur & $\mathrm{F}$ & Catherine & Full time & Drone & Y & $\mathrm{Y}$ \\
\hline Entrepreneur & M & Jeoffrey & Full time & Drone & Y & $\mathrm{N}$ \\
\hline Entrepreneur & M & Perceval & Full time & Forager & Y & $\mathrm{N}$ \\
\hline Entrepreneur & M & Jérôme & Full time & Forager & Y & $\mathrm{N}$ \\
\hline Entrepreneur & M & Maurice & Full time & Forager & $\mathrm{N}$ & $\mathrm{N}$ \\
\hline Entrepreneur & M & Corentin & Full time & Drone & $\mathrm{N}$ & $\mathrm{Y}$ \\
\hline Intrapreneur & M & Barthelemy & Full time & Drone & Y & $\mathrm{Y}$ \\
\hline Intrapreneur & M & Philippe & Full time & Forager & Y & $\mathrm{Y}$ \\
\hline Intrapreneur & M & Simon & Full time & Newbee & Y & $\mathrm{N}$ \\
\hline Entrepreneur & $\mathrm{F}$ & Anna & Full time & Nurse & $\mathrm{Y}$ & $\mathrm{N}$ \\
\hline
\end{tabular}


Table 2 - Configuration of logics for the four entrepreneurial profiles

\begin{tabular}{|c|c|c|}
\hline $\begin{array}{l}\text { Social logic } \\
\text { Commercial logic }\end{array}$ & Low familiarity & High familiarity \\
\hline High familiarity & $\begin{array}{c}\text { Drone bees } \\
n=15\end{array}$ & $\begin{array}{c}\text { Forager bees } \\
n=7\end{array}$ \\
\hline Low familiarity & $\begin{array}{l}\text { Newbees } \\
n=5\end{array}$ & $\begin{array}{c}\text { Nurse bees } \\
n=6\end{array}$ \\
\hline
\end{tabular}




\section{Building a local community of hybrid entrepreneurs}

\section{A. Identifying with peers}

1. Gathering
around common
values and
practices

Clearly there is something that is common to all entrepreneurs here, because you believe in your project, it's typically entrepreneurial, but in addition it is social entrepreneurship so there is meaning [...], you believe in a project, in a way of seeing the world, in a way where you can participate in building a better world. It relates to your identity, the meaning you give to your life, well, it's super strong, probably more than in other entrepreneurial projects that are more rational. (Emma, nurse bee, 2019)

There are things that are quite specifically related to the profile of people who integrate La Ruche. There are lots of things that we do not agree with, but there is this desire to find a consensus. It is a common value found here and among people who want to come here. (Jeoffrey, drone bee, 2011)

Being at La Ruche [gives] the feeling that you belong to a community that is built upon shared values and that is moving in the same direction [...]. Being surrounded by people who share the same desire to promote alternatives also helps to validate what you're doing and not just leave you to follow your instincts. (Sabine, forager bee, 2011)

At the time, I was interested in the social entrepreneurship identity [...], the fact that all entrepreneurs have a similar stance. It felt easier to meet people who had the same values as me and, with whom we could thus take risks. [...] It's like a kind of common energy. We fight for things that are important to us and we have a shared worldview. (Bastien, newbee, 2019)

2. Exposure to diverse socially entrepreneurial approaches
It's a space that represents the diversity of entrepreneurial approaches where the interactions allow you to cross into other areas, to move beyond your own work habits. [...] Through listening to other entrepreneurs, I have discovered a lot of new things outside of my line of business. (Patience, nurse bee, 2011)

For us the social mission must be embedded in the values, that's one thing, but in terms of viability, the business dimension must also be developed. We feel that there are entrepreneurs with whom we could work, with whom we have shared values and others with whom it will be difficult because the venture is too young, because there is no complementarity. [...] We have more business interactions with ventures comparable to us in terms of workforce size and seniority, compared with emerging projects. (Bryce, drone bee, 2011)

It was amazing to be in such an innovative place, where I learned a lot about others areas that I knew nothing about, for example related to the environment. [...] It really allowed me to get to know much more about other sectors. (Cain, forager bee, 2011)

The genius of the place was really to bring people who were a bit isolated. Together we are stronger. There were many different projects, entrepreneurs with different backgrounds, different ages, different trajectories, and so on. [...] We really had a fairly wide range of sectors and activities. It was really nice! (Samuel, newbee, 2019) 


\section{B. Building ties in a shared space}

\begin{tabular}{|l|l|}
\hline $\begin{array}{l}\text { 3. Sharing } \\
\text { inspiration and } \\
\text { motivation }\end{array}$ & $\begin{array}{l}\text { I am aware of being in a place that has a special spirit. I'm happy when I go to } \\
\text { work in the morning, which was not the case before. (Philippe, nurse bee, 2011) } \\
\text { I arrived with high expectations, at more than } 40 \text { years old, thinking: "wow, these } \\
\text { guys are living gods, they do everything right, they tick all the boxes." Well, they } \\
\text { just come out normal. But it's true that the purpose they serve is rather interesting. } \\
{[\ldots] \text { So, it reassured me about my ability to become a relevant actor in this }} \\
\text { environment. I took positive things from the experience which made me want to } \\
\text { go on. It also allowed me to have something to tell my kids that interested them. } \\
\text { When I sold databases or ERPs, [...] coming back from Saudi Arabia with a nice } \\
\text { contract signed, they didn't care. But when I told them that I hired deaf people, } \\
\text { etc., they started asking me questions, that's very satisfying, so I felt like I was } \\
\text { doing something really useful. (Corentin, drone bee, 2011) }\end{array}$ \\
\hline
\end{tabular}

We shouldn't minimize mutual support. When you have downs and you realize the neighbor has successfully overcome the same type of down before, it's great! In social entrepreneurship, as you try to tackle a severe societal problem, you inevitably develop resent with regard to the government and business sectors who don't listen to you [...]. So joining a place where you can meet with others and say "yes, let's change the world", is a strong source of motivation. (Javier, forager bee, 2011)

It was by talking to [a fellow coworker] that I thought for the first time "Wow, we can create mission-driven companies that are not associations or NGOs, they are real companies." (Flavien, newbee, 2011)

4. Sharing space $\quad$ I thought it was a nice place, both the space itself and the way it's designed to make it user friendly. [...] I loved the cafeteria, the decoration, it is not neutral as an environment, the objects, the phone booth. [...] It is offbeat, the place is made to give the feeling that we are not in a traditional place, and we get attached to it. (Philippe, nurse bee, 2019)

Many of us have left for the same reason: that thing is not intended to work. It's nice, it's idealistic, but thinking that 39 ventures can work together in the same open space, one must never have worked in a company to believe in the idea. It was unbearable. (Bryce, drone bee, 2011)

It's great to share a common place in which we feel at home, we behave here as if we were at home. We maintain the space as our common good [...]. It's an interesting work process. (Sabine, forager bee, 2011)

Working together in the same space creates bonds that are so strong that when people leave the space, they remain connected. (Bastien, newbee, 2019)

\begin{tabular}{l|l} 
5. Cultivating & The discussion times that the La Ruche team arranges create conviviality and
\end{tabular} family-like opportunities to get to know each other. It's good to share the same space, but it's even better to interact with the others. The Buzz, Happy Ruche, residents' parties, and conferences are all events that help to build ties and get to know each other. (Philippe, nurse bee, 2013)

We really created very strong bonds. And I think a lot of people from La Ruche, maintain these links because they've been in the same place. And even if they separate tomorrow, they will always be connected. (Bryce, drone bee, 2019) 


\begin{tabular}{|c|c|}
\hline & $\begin{array}{l}\text { It was a community, [...] it was equivalent to a family. Some people who for } \\
\text { some reason had to leave said: "but I will never find again what I found in La } \\
\text { Ruche, in terms of human connections and atmosphere." (Perceval, forager bee, } \\
\text { 2019) } \\
\text { The human factor is central. This differs from the dynamics of competition, } \\
\text { profitability, efficiency that generally permeate the workspace. Coworkers of La } \\
\text { Ruche work a lot but this work takes place in a context of conviviality and } \\
\text { responsibility. There is no hierarchy, we work with others because we want to. } \\
\text { (Simon, newbee, 2011) }\end{array}$ \\
\hline \multicolumn{2}{|c|}{ II. Collectively experimenting with hybridity } \\
\hline \multicolumn{2}{|c|}{ C. Developing projects as hybrid ventures } \\
\hline $\begin{array}{l}\text { 6. Sharing ideas and } \\
\text { advice }\end{array}$ & $\begin{array}{l}\text { We've come here to work together with others and it takes } 6 \text { months to discover } \\
\text { that the guy in front of you does exactly what you'd like to do, or would be your } \\
\text { ideal partner. For example, [a social entrepreneurship advocate] launched a } \\
\text { competition on sustainable housing, I heard about it by chance and so we sat } \\
\text { together [...] and then there's this other coworker working on sustainable } \\
\text { development and they didn't know about him. This means that there's a } \\
\text { problem, it doesn't work because the goal of La Ruche is precisely to enable } \\
\text { these connections. (Philippe, nurse bee, 2011) } \\
\text { If you accept that your knowledge inside La Ruche is shared freely with others, } \\
\text { you are part of the community. And all the people who join La Ruche today have } \\
\text { the feeling that they are participating in something bigger, that their knowledge } \\
\text { is available to others. [...] We create a space for professional knowledge to be } \\
\text { shared freely. It's like the Wikipedia of entrepreneurial experience. (Bryce, } \\
\text { drone bee, 2019) } \\
\text { We work on issues for which there is much left to create. If you stay alone, you } \\
\text { won't find new ideas. The best way to find new ideas is to be challenged by } \\
\text { other social entrepreneurs. La Ruche means the links between the bees, between } \\
\text { the entrepreneurs, otherwise it's nothing. (Perceval, forager bee, 2011) } \\
\text { I appreciate the freedom of being able to bring what I know to others. It helped } \\
\text { build my self-confidence to say that I could transmit something and that at my } \\
\text { level I could bring something to the others. (Annelise, newbee, 2013) }\end{array}$ \\
\hline $\begin{array}{l}\text { 7. Aiming for social } \\
\text { impact }\end{array}$ & $\begin{array}{l}\text { When I look at the entrepreneurs, the founders... we are still in this logic of social } \\
\text { transformation. None of us is doing something else. (Anna, nurse bee, 2019) } \\
\text { What makes the difference is this willingness of people to ask themselves 'what } \\
\text { is my social and environmental impact?' It's permanent and you can't find this } \\
\text { outside of La Ruche. At [La Ruche], there's always someone to remind us of this } \\
\text { [impact], which we could lose sight of when day after day we're dealing with the } \\
\text { numbers and looking for money. (Catherine, drone bee, 2011) } \\
\text { I discovered social entrepreneurship completely by chance and I met with } \\
\text { numerous fellow social entrepreneurs who supported me. In the same way, at La } \\
\text { Ruche we support each other in improving our social impact. (Sabine, forager bee, } \\
2011 \text { ) } \\
\text { I project myself into social entrepreneurship, it could be a lot of areas [where I] } \\
\text { create links between people and help them to live better. (Annelise, newbee, 2013) }\end{array}$ \\
\hline
\end{tabular}




\begin{tabular}{|c|c|}
\hline $\begin{array}{l}\text { 8. Strengthening } \\
\text { business models and } \\
\text { skills }\end{array}$ & $\begin{array}{l}\text { I really liked the possibility of having access to a certain number of business skills } \\
\text { that are useful when you put together a project. Relying on the available skills is } \\
\text { interesting. It allows you to go faster, it boosts ideas, and challenges you as an } \\
\text { entrepreneur. (Greta, nurse bee, 2019) } \\
\text { The people who are most visible are those who are purely socially entrepreneurial } \\
\text { and don't seek to make profit. At some point I wondered whether I still had my } \\
\text { place here, because people were talking about changing the world and were not } \\
\text { in a business logic, whereas I didn't want any money from the government, I } \\
\text { wanted to make business and find new clients. Now I have the impression that } \\
\text { things are changing and becoming more balanced again. (Catherine, drone bee, } \\
2011 \text { ) } \\
\text { If I've come at La Ruche, it's also to concretely respond to client expectations, } \\
\text { find new business ideas for current and potential clients. This has worked, I'm } \\
\text { happy. For me this is largely thanks to La Ruche. (Perceval, nurse bee, 2011) } \\
\text { We must not lose sight of the business model, because a subsidy is not an end in } \\
\text { itself, and anyway it will gradually decrease. (Bastien, newbee, 2019) }\end{array}$ \\
\hline $\begin{array}{l}\text { 9. Conciliating social } \\
\text { impact and financial } \\
\text { viability }\end{array}$ & $\begin{array}{l}\text { What I've found interesting at La Ruche is that we leave the binary thinking about } \\
\text { profit or not-for-profit, good or evil. Here there's a dialogue, we're no longer } \\
\text { afraid of success so it frees us from the taboo of making profit and shifts [the } \\
\text { discussion] towards 'what do we do with the profit?' This brings new ideas on } \\
\text { how to make money [...] and have it circulate in a different way. (Garance, nurse } \\
\text { bee, 2013) } \\
\text { I don't run the business in the way I did previously. But I maintained a part of my } \\
\text { previous self that is an asset too. I think especially of commercial aggressiveness } \\
\text { where we used what we learned before, but this time not in the benefit of } \\
\text { shareholders but for the sake of a higher cause. [...] Now it is for the creation of } \\
\text { employment that I fight. So, it's a little different, but on the other hand, the know- } \\
\text { how, the fight, I brought it from my previous experience. (Corentin, drone bee, } \\
\text { 2019) } \\
\text { How should I build a business plan with social impact? I'm wondering. This is } \\
\text { why I attend events such as the Buzz, to connect with others and learn methods } \\
\text { that integrate the social and economic dimensions of my activity. (Perceval, } \\
\text { forager bee, 2013) } \\
\text { I think there is a tension [...]: on one hand, we have our values and, on the other } \\
\text { hand, the economic reality that reminds us on a daily basis that we will not be } \\
\text { able to pay our electricity bills with kisses. So, you need a business model that } \\
\text { works. And to have a business model that works, it may be important precisely } \\
\text { to find the balance between head and heart. (Samuel, newbee, 2019) }\end{array}$ \\
\hline \multicolumn{2}{|c|}{ D. Developing the coworking space as a hybrid venture } \\
\hline $\begin{array}{l}\text { 10. Managing the } \\
\text { coworking space } \\
\text { as a professional } \\
\text { business }\end{array}$ & $\begin{array}{l}\text { There is a perfect match between the work of La Ruche and the work that we do } \\
\text { as entrepreneurs. La Ruche is a collaborative workspace focused on social } \\
\text { innovations, which is different from something totally associative or advocacy- } \\
\text { driven. Clearly, at La Ruche, it's something quite pragmatic actually. (Philippe, } \\
\text { nurse bee, 2011) }\end{array}$ \\
\hline
\end{tabular}




\begin{tabular}{|c|c|}
\hline & $\begin{array}{l}\text { There's been a problem with the telephone for more than } 5 \text { months. Rather than } \\
\text { playing and saying "let's have fun and organize a 'happy ruche"', in a working } \\
\text { space we should focus a bit more on things like the telephone. It makes me crazy. } \\
\text { I don't understand. (Bryce, drone bee, 2011) } \\
\text { We worked with means that were largely insufficient in relation to the needs, So } \\
\text { we did a lot of bricolage, the conditions were not ideal. (Javier, forager bee, 2019) } \\
\text { It's a friendly but professional atmosphere. The staff members are very accessible } \\
\text { but at the same time they know how to support and guide the entrepreneurs in a } \\
\text { professional way. (Simon, newbee, 2013) }\end{array}$ \\
\hline $\begin{array}{l}\text { 11. Building a } \\
\text { coworking space } \\
\text { with social impact }\end{array}$ & $\begin{array}{l}\text { There are contradictions between the values of La Ruche and their } \\
\text { implementation. There are a lot of nice values and humanistic principles, but } \\
\text { because of stressful situations we sometimes tend to leave them aside. (Patience, } \\
\text { nurse bee, 2013) } \\
\text { At some point you look into the details and wonder "what is the social problem } \\
\text { they [coworker ventures] are solving?" Sometimes it's scary, the social side has } \\
\text { been hijacked. [...] If you do something alternative, if you make Aztec jewelry, } \\
\text { it's ok, in fact they've fallen into the money trap. (Bryce, drone bee, 2011) } \\
\text { It looks alternative but it's not really. True social entrepreneurs would already } \\
\text { have a cooperative. Same for the environmental aspect. [...] What is a lacking a } \\
\text { bit is for the community to think about itself, its environmental impact, its social } \\
\text { impact. (Perceval, forager bee, 2011) } \\
\text { A lot of very young people were [...] stimulated by the values displayed by La } \\
\text { Ruche, the social entrepreneurship label. But the reality was really disappointing. } \\
\text { I know that there have been internal crises and things have finally evolved } \\
\text { positively. (Tanguy, drone bee, 2011) }\end{array}$ \\
\hline $\begin{array}{l}\text { 12. Experimenting } \\
\text { with participative } \\
\text { governance }\end{array}$ & $\begin{array}{l}\text { I regret }[\ldots] \text { the lack of transparency on the governance model of La Ruche. If } \\
\text { you don't commit yourself, you don't know. [...] I regret that there is not more } \\
\text { regular information, in particular on financial arbitrations. [...] I know how } \\
\text { much I pay rent but I don't know who decides where this money goes. (Philippe, } \\
\text { nurse bee, 2011) } \\
\text { They are very much in the theory of participative democracy, [...] more as a } \\
\text { stance than as something sincere. If we really want to give people power, we } \\
\text { give them. We don't pretend and then continue business as usual. (Barthelemy, } \\
\text { drone bee, 2011) } \\
\text { There is a very pleasant and reassuring model of governance. There is a } \\
\text { neighborhood council. It meets on a regular basis to talk about the problems of } \\
\text { entrepreneurs and it is entrepreneurs who discuss them. (Sabine, forager bee, } \\
\text { 2011) } \\
\text { Participating in the governance of La Ruche gave me innovative animation } \\
\text { methods. In internal seminars, workshops, regarding how to involve people, etc. } \\
\text { (Bastien, newbee, 2013) }\end{array}$ \\
\hline
\end{tabular}


III. Co-constructing the hybrid venturing ecosystem

\section{E. Developing collaborations}

\begin{tabular}{|l|l|}
\hline $\begin{array}{l}\text { 13. Collaborating } \\
\text { with peer social } \\
\text { entrepreneurs }\end{array}$ & $\begin{array}{l}\text { [A coworker] has enabled me to sign a deal with one of her partners. And I sub- } \\
\text { contracted some work to her. It's not only about working in the same place, it's } \\
\text { also about collaborating and providing each other opportunities. (Greta, nurse bee, } \\
\text { 2011) }\end{array}$
\end{tabular}

I've also kept [...] a lot of contacts, [...] today I still work with certain companies that I met at La Ruche, like Birdeo for example, on recruitment, which launched its activity at the same time as me there. (Barthelemy, drone bee, 2019)

When I arrived [...] I hadn't imagined that I would do things with other organisations at La Ruche. The network, yes, I was aware of that, but working together - not at all. I hadn't realised the power of all that. (Sabine, forager bee, 2013)

We made an exchange with a coworker: I offered her my training and she provided advise and trained my trainers. (Bastien, newbee, 2011)

14. Collaborating La Ruche has brought me partners, networking, and contacts. Instead of waiting with external for things to happen, things go much faster here. (Floriane, nurse bee, 2011)

stakeholders

The experience at La Ruche allowed us to interact with some major actors in the field, which we wouldn't have had if we had each remained working in our little corner. (Cain, drone bee, 2019)

This networking aspect is important and I had the opportunity to experience it. I was able to find contacts for my activity because there are complementary structures, which themselves have networks that can interest me to find partners. We jointly answered a bid with two other structures of La Ruche, together we're strong. (Perceval, forager bee, 2011)

We've been able to meet several companies who wanted to visit La Ruche and collaborate with us as social entrepreneurs. (Flavien, newbee, 2013)

\section{F. Building legitimacy as hybrid entrepreneurs}

15. Gaining visibility and outreach
We shared a real pioneering spirit [...], we mobilized collectively to make our way of entrepreneuring more visible. I think that's what remained most, beyond the operational things and even beyond the collaborations that took place, it is this state of mind where we represented something disruptive and that we became a visible example of a movement that was still quite nascent. (Anna, nurse bee, 2019)

What did I get out of it? Well, a certain culture of social entrepreneurship. [...] I came from a sector that was totally different, I did auditing, I did consulting [...]. I was not at all involved in this movement. [When] arriving at La Ruche, [...] it was quite emerging as a movement. And so, that allowed me that to discover, [...] to embark in this movement. (Barthelemy, drone bee, 2019)

It's not easy to engage in social entrepreneurship in France. So it's really useful to be in a structure where there is such mutual support, where success stories are shared and where the sector becomes more visible. (Cain, forager bee, 2019) 


\begin{tabular}{|l|l|}
\hline \multirow{1}{*}{$\begin{array}{l}\text { 16. Gaining and } \\
\text { maintaining } \\
\text { credibility as social } \\
\text { entrepreneurs }\end{array}$} & $\begin{array}{l}\text { It was exciting to contribute to building an ecosystem focused on social } \\
\text { entrepreneurship. In 2009, there was still not much light on the interest of this } \\
\text { type of economy. [...] So, it was great to be part of this emerging movement. } \\
\text { (Samuel, newbee, 2011) } \\
\text { Many entrepreneurs who've joined say: "We are at La Ruche, so we have this } \\
\text { it's not because you go through La Ruche that your venture will survive, } \\
\text { unfortunately. But it's [...] true that today La Ruche is very well known, } \\
\text { recognized, and this recognition has a positive spillover effect on the coworkers' } \\
\text { venture, that's true. (Greta, nurse bee, 2019) }\end{array}$ \\
$\begin{array}{l}\text { If people with whom I talk don't know [La Ruche], it means that they don't really } \\
\text { know the ecosystem, for me it's a way to measure [...] [whether] they really care } \\
\text { about the topic and are a relevant actor. When people know [La Ruche], they tell } \\
\text { me 'this is very good, this is where you have to be'. (Tanguy, drone bee, 2011) }\end{array}$ \\
$\begin{array}{l}\text { I've chosen La Ruche for certain reasons and then over time I've discovered that } \\
\text { the fact of being at La Ruche brought amazing credibility to my project. It helped } \\
\text { me to open doors very easily, for example at the Paris municipality. When I chose } \\
\text { to work at La Ruche, I didn't realize the image that they had in the eyes of many } \\
\text { organizations. (Sabine, forager bee, 2011) }\end{array}$ \\
$\begin{array}{l}\text { The fact of being here gives credibility. It adds something and reflects specific } \\
\text { values. And for the clients who know [the coworking space], they tell me 'ok } \\
\text { you're a start-up, but you've been accepted at La Ruche'. (Simon, newbee, 2011) }\end{array}$ \\
\hline
\end{tabular}


Figure 1-Data structure

First-order codes

Second-order codes

Aggregate dimensions

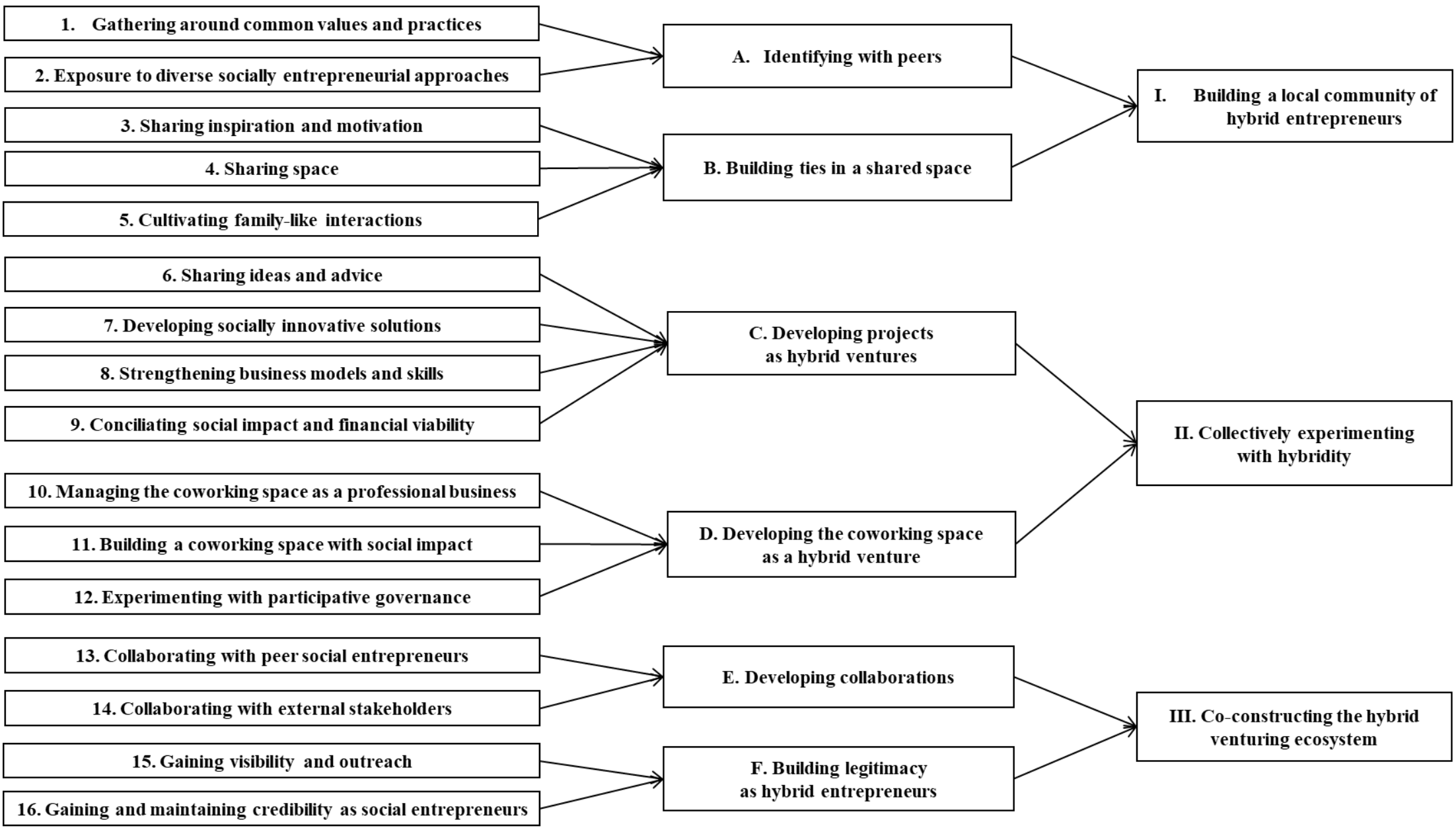


Table 4 - Summary of findings

\begin{tabular}{|c|c|c|c|c|}
\hline & Nurse bees & Drone bees & Forager bees & Newbees \\
\hline $\begin{array}{l}\text { 1. Gathering around common } \\
\text { values and practices }\end{array}$ & $\mathrm{v}$ & $\mathrm{V}$ & $\mathrm{v}$ & $\mathrm{V}$ \\
\hline $\begin{array}{l}\text { 2. Exposure to diverse socially } \\
\text { entrepreneurial approaches }\end{array}$ & $\mathrm{v}$ & \multicolumn{2}{|c|}{ Excessive diversity in maturity stages } & $\mathrm{v}$ \\
\hline $\begin{array}{l}\text { 3. Sharing inspiration and } \\
\text { motivation }\end{array}$ & $\mathrm{v}$ & $\mathrm{V}$ & $\mathrm{V}$ & $\mathrm{v}$ \\
\hline 4. Sharing space & $\begin{array}{l}\text { Excessive professionalism at } \\
\text { the expense of conviviality }\end{array}$ & $\begin{array}{l}\text { Excessive conviviality at the } \\
\text { expense of effective work }\end{array}$ & $\mathrm{V}$ & $\mathrm{v}$ \\
\hline $\begin{array}{l}\text { 5. Cultivating family-like } \\
\text { interactions }\end{array}$ & $\mathrm{v}$ & $\mathrm{v}$ & $\mathrm{V}$ & $\mathrm{v}$ \\
\hline 6. Sharing ideas and advice & $\mathrm{v}$ & $\mathrm{V}$ & $\mathrm{v}$ & $\mathrm{V}$ \\
\hline 7. Aiming for social impact & $\mathrm{v}$ & $\mathrm{V}$ & $\mathrm{v}$ & $\mathrm{V}$ \\
\hline $\begin{array}{l}\text { 8. Strengthening business models } \\
\text { and skills }\end{array}$ & Particularly in demand & In demand for other profiles & $\mathrm{v}$ & $\mathrm{v}$ \\
\hline $\begin{array}{l}\text { 9. Conciliating social impact and } \\
\text { financial viability }\end{array}$ & $\mathrm{v}$ & Not enough & $\mathrm{v}$ & $\mathrm{v}$ \\
\hline $\begin{array}{l}\text { 10. Managing the coworking } \\
\text { space as a professional business }\end{array}$ & \multicolumn{2}{|c|}{ Instances of poor business working conditions } & $\mathrm{v}$ & $\mathrm{v}$ \\
\hline $\begin{array}{l}\text { 11. Building a coworking space } \\
\text { with social impact }\end{array}$ & \multicolumn{3}{|c|}{ Limited exemplarity of the coworking space but useful insights } & $\mathrm{v}$ \\
\hline $\begin{array}{l}\text { 12. Experimenting with } \\
\text { participative governance }\end{array}$ & \multicolumn{3}{|c|}{ Limited exemplarity of the coworking space but useful insights } & $\mathrm{v}$ \\
\hline $\begin{array}{l}\text { 13. Collaborating with peer } \\
\text { social entrepreneurs }\end{array}$ & $\mathrm{v}$ & $\mathrm{V}$ & $\mathrm{V}$ & $\mathrm{v}$ \\
\hline $\begin{array}{l}\text { 14. Collaborating with external } \\
\text { stakeholders }\end{array}$ & $\mathrm{V}$ & $\mathrm{V}$ & $\mathrm{v}$ & $\mathrm{v}$ \\
\hline $\begin{array}{l}\text { 15. Gaining visibility and } \\
\text { outreach }\end{array}$ & $\mathrm{v}$ & Not enough & $\mathrm{v}$ & $\mathrm{v}$ \\
\hline $\begin{array}{l}\text { 16. Gaining and maintaining } \\
\text { credibility as social entrepreneurs }\end{array}$ & $\mathrm{v}$ & $\mathrm{v}$ & $\mathrm{v}$ & $\mathrm{v}$ \\
\hline
\end{tabular}

